\title{
Is there a place for mesenchymal stromal cell-based therapies in the therapeutic armamentarium against COVID-19?
}

\author{
Kátia Nunes da Silva 1,2,3, André Luiz Nunes Gobatto ${ }^{3}$, Zaquer Suzana Munhoz Costa-Ferro 2,3, \\ Bruno Raphael Ribeiro Cavalcante ${ }^{1}$, Alex Cleber Improta Caria ${ }^{4}$, Luciana Souza de Aragão França ${ }^{2,3}$, \\ Carolina Kymie Vasques Nonaka ${ }^{2,3}$, Fernanda de Macêdo Lima ${ }^{3}$, Miquéias Lopes-Pacheco ${ }^{5}$, \\ Patricia Rieken Macêdo Rocco ${ }^{5,6,7 \dagger}$ and Bruno Solano de Freitas Souza ${ }^{1,2,3^{* \dagger}} \mathbb{E}$
}

\begin{abstract}
The COVID-19 pandemic, caused by the rapid global spread of the novel coronavirus (SARS-CoV-2), has caused healthcare systems to collapse and led to hundreds of thousands of deaths. The clinical spectrum of COVID-19 is not only limited to local pneumonia but also represents multiple organ involvement, with potential for systemic complications. One year after the pandemic, pathophysiological knowledge has evolved, and many therapeutic advances have occurred, but mortality rates are still elevated in severe/critical COVID-19 cases. Mesenchymal stromal cells (MSCs) can exert immunomodulatory, antiviral, and pro-regenerative paracrine/endocrine actions and are therefore promising candidates for MSC-based therapies. In this review, we discuss the rationale for MSC-based therapies based on currently available preclinical and clinical evidence of safety, potential efficacy, and mechanisms of action. Finally, we present a critical analysis of the risks, limitations, challenges, and opportunities that place MSCbased products as a therapeutic strategy that may complement the current arsenal against COVID-19 and reduce the pandemic's unmet medical needs.
\end{abstract}

Keywords: COVID-19, Cell therapy, Mesenchymal stromal cells, Acute respiratory distress syndrome, SARS-CoV-2

\section{Introduction}

Coronavirus disease 2019 (COVID-19) originated in Wuhan, China, and spread rapidly to pandemic levels, resulting in high morbidity and mortality and causing healthcare systems to collapse worldwide. The causative agent, severe acute respiratory syndrome coronavirus 2 (SARS-CoV-2), is a positive-sense, single-stranded RNA virus of the family Coronaviridae. The virus is

\footnotetext{
* Correspondence: bruno.solano@fiocruz.br

†Patricia Rieken Macêdo Rocco and Bruno Solano de Freitas Souza share senior authorship

'Goncalo Moniz Institute, Oswaldo Cruz Foundation (FIOCRUZ), Rua Waldemar Falcão, 121, Candeal, Salvador, Bahia 40296-710, Brazil 2D'Or Institute for Research and Education (IDOR), Salvador, Brazil Full list of author information is available at the end of the article
}

transmitted among humans, mainly through respiratory droplets [1]. Most infected individuals remain asymptomatic or have mild respiratory tract symptoms; moderate to severe cases with pneumonia and acute respiratory distress syndrome (ARDS) are associated with the need for long-term hospitalization in intensive care units, prolonged ventilatory assistance, high mortality rates, and potential long-term morbidity in survivors [2].

Although immune responses are critical in controlling and eradicating viral infections, SARS-CoV-2 has been shown to induce an exacerbated inflammatory response, which plays a central role in the pathogenesis and progression of severe COVID-19 [3]. The implications of combined inflammatory and viral-mediated damage may

\section{BMC}

(c) The Author(s). 2021 Open Access This article is licensed under a Creative Commons Attribution 4.0 International License, which permits use, sharing, adaptation, distribution and reproduction in any medium or format, as long as you give appropriate credit to the original author(s) and the source, provide a link to the Creative Commons licence, and indicate if changes were made. The images or other third party material in this article are included in the article's Creative Commons licence, unless indicated otherwise in a credit line to the material. If material is not included in the article's Creative Commons licence and your intended use is not permitted by statutory regulation or exceeds the permitted use, you will need to obtain permission directly from the copyright holder. To view a copy of this licence, visit http://creativecommons.org/licenses/by/4.0/ The Creative Commons Public Domain Dedication waiver (http://creativecommons.org/publicdomain/zero/1.0/) applies to the data made available in this article, unless otherwise stated in a credit line to the data. 
extend to multiple organ dysfunction syndrome [4, 5]. Since the early phase of the pandemic, different strategies have been investigated for the treatment of COVID-19 pneumonia, including antiviral agents, antibiotics, anticoagulants, and immunomodulatory agents, among others [5, 6]. However, only a few of these studies have consistently shown a clinical benefit, as shown for dexamethasone, which significantly decreased 28-day mortality among hospitalized patients requiring supplemental oxygen [7]. The use of the antiviral remdesivir was also associated with a decreased length of hospital stay, although no significant effects were found in terms of reducing mortality [8]. Based on the finding of elevated interleukin-6 (IL-6) serum levels in COVID-19 patients-associated with disease severity and mortalitytocilizumab and sarilumab, recombinant human monoclonal antibody IL-6R $\alpha$ antagonists, have also been considered, with conflicting results [9-19]. Recently, the results of the RECOVERY trial, which included 4116 adults with severe COVID-19 at 131 sites in the UK, showed reduced mortality and invasive mechanical ventilation requirements [17].

In addition to pharmacological therapy, immunization strategies targeting prevention or early treatment have proven to be crucial. Passive immunization through infusion of convalescent plasma or monoclonal antibodies has demonstrated the potential to treat the disease, especially if applied early [20-23]. Now that vaccines are available, significant attention has shifted to accelerating worldwide immunization strategies. The slow progression of such programs, along with the emergence of new SARS-CoV-2 variants that already show some degree of escape to the vaccine-induced immune response, highlights the relevance and urgency of identifying novel therapies [24-26]. Accordingly, current therapeutic approaches are insufficient to prevent extended periods of severe disease and progression to chronic lung injury and fibrosis in those who have recovered [27]. There is still an urgent need to improve supportive care in severe cases of COVID-19 and identify effective treatments that can prevent deterioration and decrease the mortality rate.

Cell-based therapies are currently being tested in clinical trials or on a compassionate-use basis to increase the survival of patients with severe COVID-19 pneumonia [28]. These therapies are based on the transfer of specific types of cells to control inflammation and stimulate endogenous repair or regenerative mechanisms. To date, most clinical protocols have evaluated the use of mesenchymal stromal cells (MSCs) obtained from different tissue sources, including the umbilical cord, adipose tissue, and bone marrow. In this review, we discuss the rationale, mechanisms of action, potential risks and benefits, and current challenges in translating MSC-based therapies into the armamentarium of therapeutic options against severe COVID-19.

\section{Pathophysiology of COVID-19}

Current understanding of the pathophysiology of COVID-19 has been established through a comparative analysis of extensive data from previous studies on SARS-CoV and Middle East respiratory syndrome-CoV, along with reports of experimental and postmortem studies of SARS-CoV-2 infection. Viral particles enter target cells through an interaction of the coronavirus spike (S) protein with host cell angiotensin-converting enzyme 2 (ACE2), a proteolytic process that involves the transmembrane protease, serine 2 (TMPRSS2), followed by a cascade of intracellular signaling [29]. Although the respiratory tract has been shown to serve as an initial reservoir for viral infection and replication-especially the nasal and laryngeal mucosa-ACE2 receptors are located not only in lung structural cells but also in epithelial and endothelial cells of the heart, bowel, kidney, and brain, as well as vascular smooth muscle cells. Therefore, the clinical spectrum of COVID-19 is not limited to local pneumonia, but rather represents multiple organ involvement with potential for systemic complications $[4,30,31]$.

Under normal physiological conditions, ACE2 has a protective role in lung tissue because it is a component of the renin-angiotensin-aldosterone system responsible for converting angiotensin II to angiotensin [1-7], which has vasodilator and antifibrotic activities [32, 33]. However, the interaction of SARS-CoV-2 with ACE2 prevents the latter from exerting its protective activity, resulting in dysfunction of the renin-angiotensinaldosterone system and vasoconstrictive, proinflammatory, and pro-fibrotic actions due to the accumulation of angiotensin II [34]. Interestingly, ACE2 demethylation status seems to increase after SARS-CoV-2 infection, increasing ACE2 gene expression, possibly in response to exacerbated oxidative stress [35].

Several pathological mechanisms are involved in the disease progression and multiple organ dysfunction in COVID-19. These include direct viral toxicity, cell death mechanisms, endothelial dysfunction, thromboinflammation, dysregulation of the immune response, and tissue fibrosis [32]. Individuals who progress to acute respiratory failure associated with COVID-19 may develop an intense systemic inflammatory process in response to rapid viral replication and cell injury [36]. In lung tissue, postmortem studies have demonstrated diffuse alveolar damage, hyaline membrane formation, massive capillary congestion, microthrombi, inflammatory infiltrates, and consolidation with extensive fibrosis. In peripheral blood, lymphopenia is observed with substantially reduced $\mathrm{CD}^{+}$and $\mathrm{CD}^{+}$cell counts; however, these 
lymphocytes are activated, with an increase in the Th17 cell population $[11,37]$.

Cell death and inflammation appear to be associated with the pathogenesis of SARS-CoV-2 infection. SARS$\mathrm{CoV}-2$ infection has been shown to induce caspase- 8 activation, a key regulator of different types of cell death, including apoptosis, pyroptosis, and necroptosis, and convert the pro-inflammatory cytokine IL-1 $\beta$ into its bioactive form. Moreover, the combination of increased production and release of combined TNF- $\alpha$ and IFN- $\gamma$ has been linked with a process of PANptosis [38-40]. It has been shown that the SARS-CoV-2 accessory protein ORF-3 induces apoptosis through the extrinsic pathway, leading to caspase-8 cleavage without interfering with Bcl-2 levels [41]. Evidence of extensive apoptotic signals was detected in the lung tissues of humans and nonhuman primates following SARS-CoV-2 infection [42]. Pyroptosis is also induced in SARS-CoV-2-infected cells, triggered by inflammasome-mediated caspase $1 / 4 / 5 / 11$ activation [43]. Caspase 1-dependent pyroptosis and the processing and release of the inflammatory cytokines IL18 and IL-1 $\beta$ [44] induce interferon (IFN) $\gamma$ p production and activation of $\mathrm{T}$ cells and macrophages, among others [45].

Type I IFN (IFN- $\alpha$, IFN- $\beta$ ) activation is triggered by viral entry, but patients that progress to severe COVID19 seem to present a delayed type I IFN response [46, 47]. While type I IFN products play important roles in early-phase antiviral defense, a delayed response has been associated with increased viral replication, intense parenchymal influx of inflammatory cells, and overexpression of pro-inflammatory cytokines [48].

Patients with severe COVID-19 show increased levels of IL-6, IL-8, IL-10, IL-2R, and tumor necrosis factor (TNF)- $\alpha$ compared to those with mild to moderate disease [49]. High concentrations of pro-inflammatory cytokines are associated with disease severity and $\mathrm{T}$ cell depletion. Lymphopenia, which affects both CD4 and CD8 subsets, is a very frequent finding. In severe/critical COVID-19 cases, $\mathrm{T}$ cell dysregulation has been shown, with the expression of hyperactivation markers and lower frequencies of terminally differentiated $\mathrm{T}$ cell subsets [50]. This contributes to a failure to adequate viral infection control that, combined with a hyperinflammatory state, contributes to more alveolar damage, establishment of ARDS, vascular hyperpermeability, and progression to multiorgan failure [51].

These findings suggest that the use of a therapeutic approach that suppresses production of proinflammatory cytokines and reduces the exuberant inflammatory response may be the key to reducing multiple organ dysfunction and increasing the survival of individuals with severe COVID-19. Nevertheless, this should be accompanied by an effective antiviral to avoid a superinfection state. Other crucial mechanistic targets should focus on vascular dysfunction, oxidative stress, and coagulation to promote repair mechanisms and restore pulmonary epithelial cell function.

\section{Mesenchymal stromal cells}

MSCs were coined by Caplan in the 1990s to define mesenchymal stem cells, a type of multipotent stem cell with the potential to differentiate into cells of mesodermal origin, such as chondrocytes, osteocytes, and adipocytes and that could display pluripotency under certain in vitro conditions [52]. After the acknowledgment that MSCs are not clonal and are actually a heterogeneous population by nature, the acronym MSCs were then redefined to fit the currently accepted nomenclature: mesenchymal stromal cells. Finally, data collected from the application of MSCs in regenerative medicine have clearly shown that multipotency does not explain the beneficial actions exerted by these cells [53]. MSCs release anti-inflammatory, antibacterial, antiviral, and immunoregulatory factors locally at the lesion site [54]. Studies have demonstrated that, in response to tissue damage signals, MSCs release paracrine/endocrine factors that help control inflammation and stimulate tissue regeneration by endogenous mechanisms [55]. The recognition of these immunomodulatory/trophic actions with beneficial effects and migratory capacity in different tissues makes MSCs a unique therapeutic strategy [56, 57]. These MSC characteristics have also led their original describer, Caplan, to call for a further nomenclature change to medicinal signaling cells [53].

Nomenclature issues aside, the putative role of MSCs in vivo would be to participate in tissue homeostasis and to support tissue-resident stem cells (i.e., hematopoietic stem cells in the bone marrow), in addition to being a source of specialized cells of mesodermal lineage. The regulation of tissue homeostasis is mediated by cell signaling through the production of trophic factors, release of extracellular vesicles (EVs), etc. [58]. MSCs are morphologically similar to fibroblasts and strongly adhere to plastic surfaces [59]. MSCs also express some of their markers with other stromal cells, which makes them difficult to identify in vivo. However, some studies have suggested that pericytes are their in vivo counterparts [60].

MSCs can be obtained from different sources, including adult tissues (such as bone marrow and adipose tissue) and perinatal tissues (such as the umbilical cord) [61]. MSCs are characterized by immunophenotyping and functional assays, and multipotency was demonstrated by chondrogenic, osteogenic, and adipogenic differentiation assays in vitro. In 2006, a consensus statement by the International Society for Cellular Therapy established minimum criteria for identification of 
human MSCs based on the characteristics of these cells: (1) adhesion to plastic when maintained in standard culture conditions, fibroblast-like morphology; (2) expression (>95\%) of the surface molecules CD105, CD73, and CD90, but not of hematopoietic markers $(<2 \%)$, such as CD45, CD34, CD14 or CD11b, CD79 or CD19, and HLA-DR; and (3) ability to differentiate into osteoblasts, adipocytes, and chondroblasts in vitro [52]. This minimal characterization should be complemented by evaluation of additional cell markers and biological properties (e.g., potency assays) that may be relevant in the context of each intended clinical application.

The clinical applications of MSCs currently under investigation or authorized for marketing are based on their biological functions, including (1) high proliferative capacity, allowing sufficient in vitro expansion for utilization in autologous or allogeneic applications; (2) preferential migration toward inflammatory/injured sites, allowing both local and systemic administration, and (3) immunomodulatory/trophic actions [58] (Figs. 1 and 2).

\section{MSC-based therapy for COVID-19 pneumonia: potential mechanisms of action and therapeutic effects}

In experimental ARDS, MSCs have been shown to promote anti-inflammatory and antimicrobial effects, tissue repair, and restoration of the alveolar epithelium and vascular endothelium via paracrine factors [62,63]. Given that the mechanism of COVID-19 respiratory failure has certain similarities with ARDS, MSC therapy may improve lung function and promote endogenous repair in alveolar epithelial and vascular endothelial cells. The mechanisms by which MSCs exert these effects include paracrine activity, transfer of organelles and molecules (such as RNAs, microRNAs, proteins, peptides, cytokines, growth factors), and release of EVs $[64,65]$. Depending on the environment they encounter, MSCs release mediators with antiapoptotic, immunomodulatory, antifibrotic, chemoattractant, or proangiogenic effects, among others. Interestingly, MSCs do not express ACE2 and are therefore relatively protected from SARS-CoV-2 infection [66].

The major mechanisms underlying MSC-based therapy rely on their interactions with target cells in injured tissues [67]. Thus, the route of administration is key to the outcome of cell therapies. Intravenous administration has been the most utilized, including in studies on COVID-19 and ARDS [68]. This is particularly important because individuals with severe COVID-19 are already extremely debilitated, and therefore, a peripheral vein could be easily accessed to infuse MSCs intravenously. Moreover, MSC biodistribution studies in animals have consistently shown four main results after intravenous administration of MSCs: (1) widespread systemic distribution of cells; (2) early accumulation in the lungs, followed by the liver and spleen; (3) directed migration toward injury sites; and (4) short-term persistence in tissues after infusion [69-74]. Interestingly, similar results were observed in humans [75]. The accumulation of intravenously administered MSCs in the lungs is the result of the initial capillary network that these cells first encounter and where they may become trapped, due not only to their size but also to the increased expression of adhesion molecules and chemokines (such as stromal cell-derived factor-1, a known chemotactic agent for MSCs) in the setting of injury and inflammation [76, 77].

Nevertheless, the brief persistence of MSCs in lung tissue might be explained by the fact that most infused cells actually become apoptotic and undergo phagocytosis by alveolar macrophages. Interestingly, this is another mechanism by which MSCs can shift inflammatory macrophages (M1) toward an antiinflammatory or regulatory (M2) phenotype [78, 79]. As stated earlier, MSC-based therapy may contribute to a reduction in the levels of pro-inflammatory cytokines and chemokines in COVID-19 by responding to the

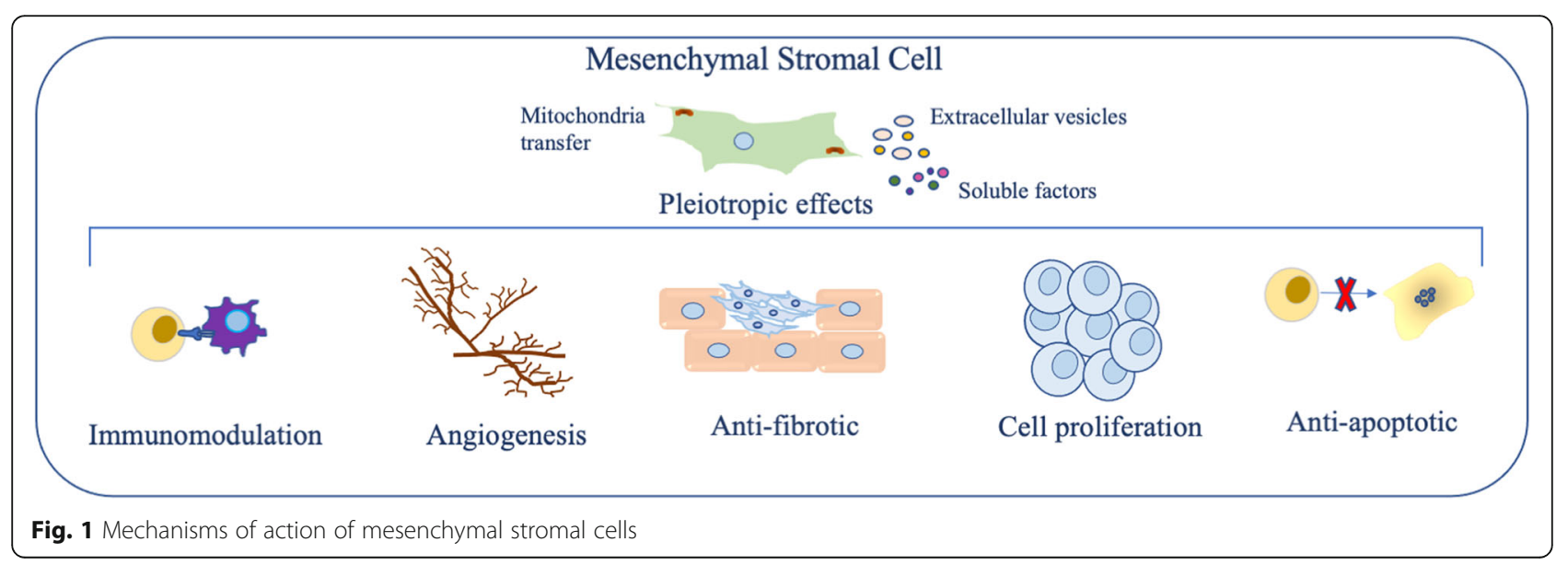




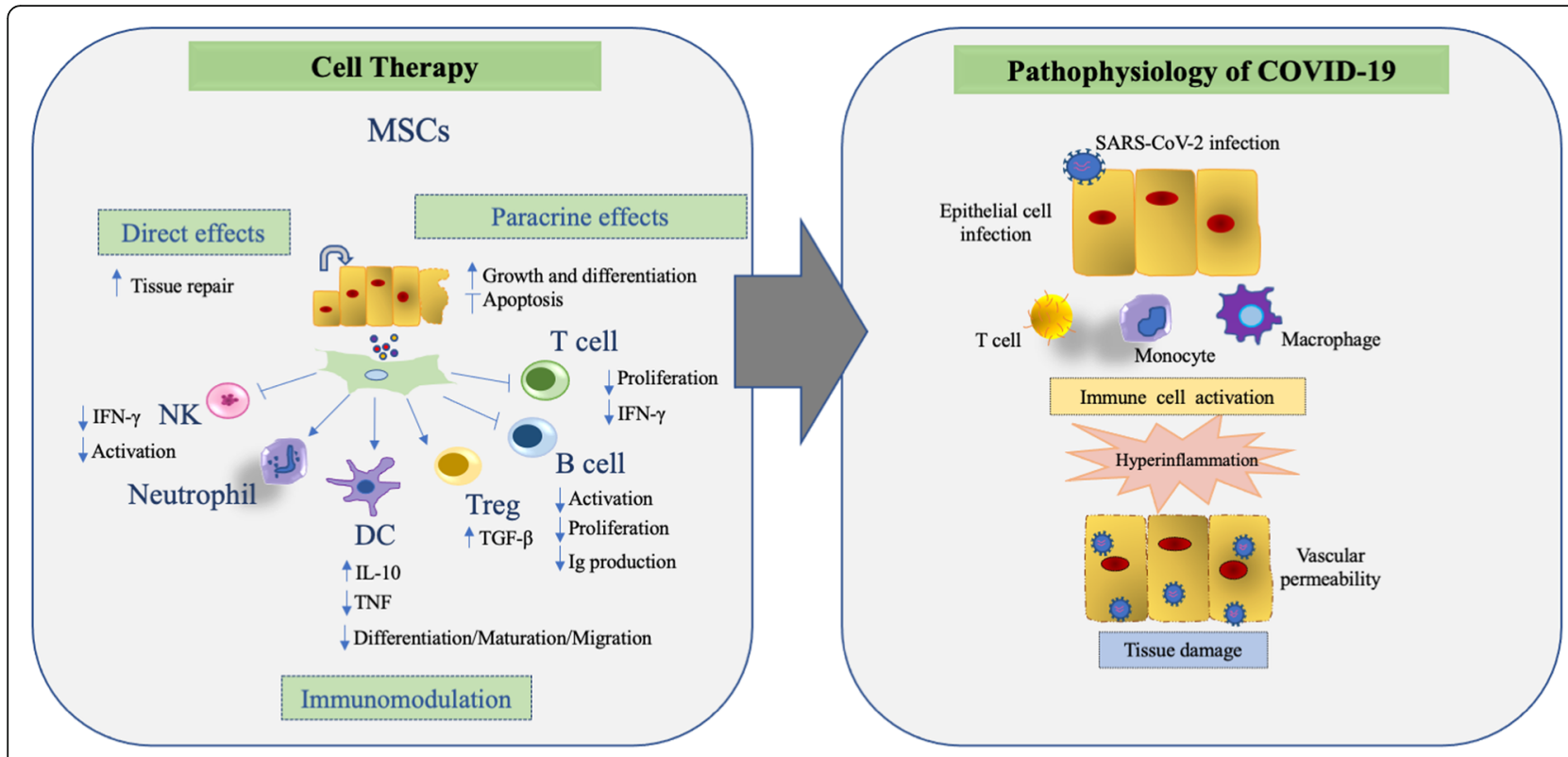

Fig. 2 Mesenchymal stromal cells (MSCs) and immune modulation in COVID-19. DC, dendritic cell; IFN- $\gamma$, interferon- $\gamma$; IL, interleukin; TGF- $\beta$, transforming growth factor- $\beta$; TNF, tumor necrosis factor; Treg, regulatory $T$ cell

hyperinflammatory microenvironment through the release of paracrine/immunomodulatory factors, including transforming growth factor- $\beta$, hepatocyte growth factor, indoleamine 2,3-dioxygenase, and IL-10 [36, 66]. Some studies have also reported the involvement of galectins, such as Gal-3, in MSC-mediated immunomodulation [80-82]. Indeed, these effects not only could be useful in treating COVID-19 pneumonia, but could also have a positive impact on the extrapulmonary complications of COVID-19. Indeed, MSCs present pro-survival actions, due to their ability to modulate processes of regulated cell death, including apoptosis, necroptosis, and pyroptosis, which are involved in the pathophysiology of COVID-19 [38, 40].

In addition to the abovementioned properties, MSCs release EVs (i.e., exosomes and microvesicles) to communicate with the surrounding microenvironment and exert pro-regenerative and immunomodulatory functions. The released EVs carry molecules such as cytokines, growth factors, chemokines, microRNAs, RNAs, enzymes, and hormones [83]. Interestingly, MSCs also act by transferring their healthy mitochondria to host cells through EVs, membrane nanotunneling, or gap junctions, a mechanism that can help restore normal epithelial and immune cell functions [84]. Transferred mitochondria are functionally active and dampen oxidative stress in recipient cells, restoring normal epithelial cell functions, such as surfactant secretion, and increasing phagocytic activity in macrophages [85]. Oxidative stress is associated with hyperinflammation in a reciprocal feedback loop, which has been shown to boost alveolar tissue damage in COVID-19 [86-90]. Data from studies on preclinical models of lung diseases, such as acute lung injury, suggest that mitochondrial transfer of MSCs occurs in vivo and may be in part responsible for certain beneficial effects observed in these models [9193].

Besides immunomodulatory mechanisms, MSCs have demonstrated certain antiviral activity, as reviewed elsewhere [28]. In viral infections, MSCs stimulate the expression of IFN-I, which leads to an antiviral response in cells [94]. Besides the expression of IFN-stimulated genes (ISGs), MSCs also secrete indoleamine-2,3-dioxygenase (IDO) in response to pro-inflammatory microenvironments [95], which is one of the main immunomodulatory mechanisms of MSCs and has also been shown to possess antiviral properties [96]. Finally, miRNA delivery through the release of EVs may interfere with viral replication [97].

A recent preclinical trial in a sheep model of ARDS demonstrated a significant reduction in lung injury after treatment with MSCs [98]. MSCs were also able to attenuate the progression of chronic obstructive pulmonary disease (COPD), reducing endothelial cell apoptosis and oxidative stress in rats [99]. MSCs promote the transfer of mitochondria to cells that are damaged by oxidative stress, improving their mitochondrial bioenergetics, inducing cell regeneration, and improving the function of several organs, such as the lungs, heart, and brain [100]. In addition, Romieu-Mourez et al. demonstrated in vivo that toll-like receptor-activated MSCs increased immune responses and could be used in a cell- 
based vaccine [101]. Khatri et al. [102] found that systemic administration of MSC-EVs in a pig model of influenza virus-induced acute lung injury was able to significantly reduce the infiltration of inflammatory cells to the lungs and reduce the death of alveolar epithelium cells. They also found that MSC-EVs exhibited an immunomodulatory effect by suppressing TNF- $\alpha$ and increasing IL-10 secretion in the alveolus after injury.

Another MSC source relies on the differentiation of human-induced pluripotent stem cells (iPSCs). These iPSC-MSCs have been shown to suppress lung inflammation and decrease mitochondrial dysfunction and oxidative stress [92, 93], which are key factors in the pathophysiology of COPD [103] and also play an important role in infections with viruses such as influenza [104], human papillomavirus [105], SARS-CoV [106], and SARS-CoV-2 [107].

To date, there are no studies showing the effects of MSCs on inflammation or oxidative stress in SARSCoV-2, whether in vivo or in vitro; however, the beneficial effects of MSCs on the inflammatory profile of other viral infections have been demonstrated. In this context, MSC administration reduced lung inflammation, increased body weight, and improved survival in $\mathrm{H} 5 \mathrm{~N} 1$ virus-infected aged mice [108] and was effective in restoring impaired alveolar fluid clearance and protein permeability of H5N1-infected human alveolar epithelial cells [109]. Similarly, MSCs suppressed pulmonary edema and inflammation and improved gas exchange in mice infected with the H9N2 avian subtype of influenza [110]. However, MSCs were not effective in reducing lung inflammation or increasing survival in influenza virus-infected mice [111] and had no beneficial effect on H1N1 infection [112]. Further investigations are needed to better understand the differences in the therapeutic efficacy of specific viruses.

\section{Potential risks of MSC-based therapies}

Despite extensive investigations of cell-based therapies, MSC administration is not completely free of potential risks. Adverse events might include infusion reactions, allergic reactions, secondary infections, and thromboembolic events [113]. The latter is a particular concern in the context of COVID-19 because the disease has been associated with a hypercoagulable state [114]. These risks are increased when considering intravenous injections and can be reduced by utilizing other administration routes, such as intratracheal administration. The risk of environmental contamination with aerosols, along with the poor feasibility of administering fluids to hypoxemic patients, however, has favored the use of the intravenous route of administration in most ongoing studies on cell-based therapy for COVID-19. The safety intravenous route for MSC administration was previously demonstrated in ARDS, even at high cell doses [115].

The potential risk of thromboembolic events associated with intravenous infusions of high doses of MSCs has long been known in animal studies, with a few reports in humans $[116,117]$. This procoagulant activity is related to the high expression of tissue factor (TF/ $\mathrm{CD} 142$ ), which can be found in some MSC isolates and sources and leads to an increased risk of instant bloodmediated inflammatory reaction and clot formation [118]. Such events are also known to occur after intravenous infusion of pancreatic islets or hepatocytes [119, 120]. Among MSCs, adipose tissue- and amniotic fluidderived MSCs consistently show high expression of TF, whereas negligible expression of TF is found in MSCs from other sources, such as the bone marrow [121]. Considering that the expression level of TF is highly variable among MSC isolates and tends to increase with passage, duration of culture expansion, and poor quality of culture conditions, it is reasonable that MSCs intended for clinical use be checked and evaluated for TF expression and undergo ex vivo coagulation studies (e.g., thromboelastography) $[118,122]$.

MSC-based products offer several advantages for clinical application, including the ability to be cryopreserved, isolated from allogeneic donors, and available for offthe-shelf use to treat COVID-19. Allogeneic infusion of MSCs from third parties is allowed because these cells do not express $\mathrm{ABO}$ antigens, are immune-evasive, and show low immunogenicity due to the very low expression of major histocompatibility complex [123]. Repeated administration of MSCs, however, leads to the detection of anti-HLA antibodies, suggesting potential alloreactivity [124]. Although this finding might compromise the long-term permanence of MSCs and their progeny in regenerative therapies in which cell replacement is required, this would not compromise therapeutic efficacy in acute disease settings, such as COVID19, in which immunomodulatory and pro-regenerative actions are dependent on short-term cell signaling [125]. Finally, it is important to emphasize that although MSCs do not express $A B O$ antigens, these cells can be "contaminated" with $\mathrm{ABO}$ antigens in certain bioprocessing protocols that utilize human serum as a supplement. Alternatives, such as the use of platelet lysate [126], are available to establish an MSC bioprocess free of such contaminants.

Cryopreserved MSC products have great advantages over fresh products in terms of their feasibility for clinical applications and off-the-shelf availability, because they are fully characterized and confirmed sterile before infusion, characteristics that are simply not attainable with fresh products [127]. They are also amenable to transport between production sites and infusion sites 
without losing viability, as long as the temperature is monitored. Typically, these products are transported and thawed at the bedside, allowing infusion to begin within minutes to maintain cell viability. However, this procedure requires cell infusion in a cryoprotectant solution, which commonly contains dimethyl sulfoxide. This may lead to an acute toxicity syndrome that includes skin reactions, headache, dizziness, nausea, vomiting, and allergic reactions [128]. Premedication with antihistamines, commonly used in the transplantation of hematopoietic progenitor cells in clinical practice, can prevent these events [129].

The risk of secondary infections is potentiated by the use of fresh cell-based products when the results of microbiological testing are released only after the product has been infused into a patient. There is also the theoretical possibility that a state of immunosuppression induced by MSCs would allow pathogens to evade the immune response and establish secondary infections, especially in critically ill patients $[130,131]$. Data from robust clinical trials of MSC-based therapies in COVID-19 have yet to be published; therefore, this possibility is speculative and conflicts with data from several preclinical studies in which MSC treatment has been shown to help the immune system fight bacteria through direct and indirect antimicrobial actions [132].

Indeed, cell-based therapies have been associated with a risk of long-term persistence, ectopic tissue formation, or tumorigenesis. Although this risk is much more strongly linked with pluripotent cell-derived products, ex vivo expansion may be associated with genetic instability and changes in cell behavior [133]. This highlights the importance of using cells that have not undergone extensive ex vivo population doublings and monitoring the genetic stability of MSCs, at least by karyotyping [134]. MSCs have been extensively used in clinical protocols, and thousands of patients have received such therapies, which are considered quite safe in long-term analyses as long as all controls have been followed during bioprocessing [135].

Zheng et al. [136] randomized 12 patients with ARDS 1:1 to receive allogeneic adipose-derived MSCs or placebo. Patients received a single intravenous dose of $1 \times$ $10^{6}$ cells $/ \mathrm{kg}$ body weight or saline. In relation to MSC administration, there were no infusion toxicities or serious adverse events and no significant differences in the overall number of adverse events between the groups. Duration of hospital stay, ventilator-free days, and ICUfree days at day 28 after treatment were similar. There were no changes in the biomarkers of interest in the placebo group. In the MSC group, serum surfactant protein D (SP-D) levels at day 5 were significantly lower than those on day $0(P=0.027)$, although the changes in IL-8 levels were not significant. The IL-6 levels at day 5 showed a nonsignificant tendency toward lower levels compared with baseline. The study reported a good safety profile of adipose-derived MSC administration in patients with ARDS.

In 2015, Wilson et al. conducted a multicenter, openlabel, dose-escalation, phase 1 clinical trial in patients with ARDS [137]. The first three patients were treated with low-dose MSCs $\left(1 \times 10^{6}\right.$ cells $/ \mathrm{kg}$ predicted body weight $[\mathrm{PBW}])$, the next three patients received intermediatedose MSCs $\left(5 \times 10^{6}\right.$ cells $/ \mathrm{kg}$ PBW), and the final three patients received high-dose MSCs $\left(10 \times 10^{6}\right.$ cells $\left./ \mathrm{kg} \mathrm{PBW}\right)$. Pre-specified infusion-associated events or treatmentrelated adverse events were not reported in any of the nine patients. However, subsequent identification of serious adverse events occurred in three patients during the weeks after the infusion: one of them died on study day 9, another died on study day 31 , and one patient was revealed to have multiple embolic age-indeterminate infarcts of the spleen, kidneys, and brain that were thought to have occurred before the MSC infusion based on magnetic resonance imaging results. None of these severe adverse events were considered MSC-related.

Matthay et al. performed a phase 2a randomized clinical trial [115]. Sixty patients were randomly assigned 2:1 to receive either $10 \times 10^{6} / \mathrm{kg}$ PBW MSCs or placebo. None of the patients experienced any of the predefined MSCrelated hemodynamic or respiratory adverse events. One patient in the MSC group died within 24 h of MSC infusion, which was judged to be unrelated. Furthermore, 28day mortality did not differ between the groups $(30 \%$ in the MSC group versus $15 \%$ in the placebo group; odds ratio, 2.4 ; 95\% confidence interval, $0.5-15.1$ ).

To study influenza-associated ARDS, Chen et al. [138] enrolled 61 patients with H7N9-induced ARDS in a nonrandomized clinical trial; 17 patients received allogeneic menstrual blood-derived MSCs. The experimental group had lower mortality rates (17.6\% versus $54.5 \%$ in the experimental and control groups, respectively). These data indicate that MSC therapy is a safe and effective treatment for patients with severe lung disease induced by H7N9. In addition, MSC transplantation did not result in harmful effects over 5 years of follow-up.

Finally, a recent meta-analysis of MSC-based therapies to treat ARDS revealed a favorable trend toward reduced mortality and inflammatory biomarkers, as well as improved pulmonary function and radiographic data. Moreover, despite significant variation in terms of protocols, cell sources, and dosage, no serious adverse events were reported in the studies evaluated, which included a total of 117 patients [68].

\section{Evidence from clinical studies COVID-19}

Clinical experience with cell-based therapies for COVID-19 remains limited. Although multiple clinical 
trials are registered in public databases, such as clinicaltrials.gov (Table 1), only preliminary results from a few clinical studies have been published (Table 2) [66, 130, 139-154]. Many translational gaps have led to a tremendous variety in protocols, cell sources, and dosage regimens; there is also great heterogeneity in clinical presentations and stages of the disease. For instance, current knowledge is not sufficient to give support to any of the following aspects: (1) cell dose (which can be fixed or calculated by body mass); (2) use of cryopreserved versus fresh cells (i.e., whether MSCs can recover and function in vivo immediately after being thawed and infused); (3) whether any specific cell source might be more suitable, safe, and effective; and (4) the therapeutic window and expected results $[28,155]$.

The first SARS-CoV-2 case treated with stem cells has been reported in China [147]. A 65-year-old patient with severe pneumonia, respiratory failure, and multiorgan failure requiring mechanical ventilation was treated with three doses of umbilical cord MSCs 3 days apart, with impressive improvements in clinical and laboratory parameters a few days after MSC infusion. In a small clinical trial [66], the investigators compared seven patients (one critically severe, four severe, and two non-severe) infected with SARS-CoV-2 who received one dose of MSC therapy versus three patients in the control group (all severely ill) who received placebo. After 2-4 days, all symptoms resolved in the intervention group and no adverse events were observed. In the control group, only one patient recovered. However, both trials had limitations. The first [147] is a case report, and the patient could have improved despite cell therapy. The latter [66] is a small, poorly controlled, nonrandomized clinical trial. There is no description of how the control group was chosen, no sample size calculation, and no primary outcome, and due to the small number of patients, no conclusion was reached. In summary, the trial was powered only for hypothesis generation.

Additional case reports have described the intravenous use of umbilical cord mesenchymal stem cells (UCMSCs; $1 \times 10^{6}$ cells $/ \mathrm{kg}$ ), alone or with convalescent plasma, in cases of severe COVID-19. Interestingly, $\mathrm{CD}^{+}, \mathrm{CD}^{+}$, and $\mathrm{CD} 8^{+} \mathrm{T}$ cell counts increased after cell therapy, along with a reduction in the levels of proinflammatory cytokines and other markers. A recent case series of patients with COVID-19 with acute respiratory failure $(n=25)$ assessed the effect of MSCs $(1$ $\times 10^{6}$ cells $\left./ \mathrm{kg}\right)$ administered in one $(n=7)$, two $(n=7)$, or three $(n=11)$ infusions. The authors reported no fatalities and found clinical and/or radiologic improvements in all cases. Laboratory markers of inflammation were not altered, but serum levels of lactate, cardiac troponin $\mathrm{T}$, and creatine kinase (CK)-MB increased significantly after MSC therapy. The authors also reported side effects in three patients, including liver dysfunction, heart failure, and allergic rash [141]. The lack of data on cell origin and characterization (i.e., TF expression) does not allow detailed analysis of the results, which contrasts with previously published data (lack of evidence for immunomodulatory actions along with organ dysfunction) and could be the result of heterogeneity between the evaluated cell products.

Recently, a single-center, double-blind, phase $1 / 2$ a randomized study designed by Lanzoni et al. [154] was performed in which UC-MSCs were systemically administered to assess their safety and explore efficacy in 24 COVID-19 ARDS patients. The eligibility criteria were hospitalized patients diagnosed with COVID-19 and at least 18 years of age. Twelve patients were allocated to UC-MSC treatment, and the other 12 were allocated to the control group. Two doses of $100 \pm 20 \times 10^{6}$ UC-MSCs or vehicle solution were administered to the patients over intravenous (IV) infusion for $10 \pm 5 \mathrm{~min}$, on days 0 and 3 in both groups. The results of this trial indicate that UC-MSC infusions in COVID-19 patients with ARDS are safe. In terms of efficacy, 28 days after the last infusion, a significant improvement in patient survival was observed, with $91 \%$ in the UC-MSC group and $42 \%$ in the control group. The UC-MSC treatment group is characterized by a reduction in the levels of inflammatory molecules, including IFN- $\gamma$, IL-6, and TNF$\alpha$ cytokines, and regulated on activation, normal $\mathrm{T}$ cell expressed and secreted chemokine (RANTES) in COVID-19 patients. Indeed, UC-MSC treatment was associated with a significant reduction in no serious adverse events (SAEs), mortality, and time to recovery compared with controls.

Finally, there is a possibility of developing EV-based cell-free therapies for COVID-19. In one study, patients with COVID-19 and moderate to severe ARDS received a single intravenous infusion of bone marrow MSC-derived exosomes, which was well tolerated and led to improvements in oxygenation and amelioration of inflammatory markers [140]. However, the study did not adequately report the product characterization and dose.

\section{Challenges, access, and therapeutic window}

Several challenges must still be overcome to translate MSC-based therapies into the armamentarium of therapeutic options against COVID-19. There are challenges involved translating all methods and processes to obtain advanced therapy medicinal products, complex in nature, to reach GxP (good manufacturing/clinical/laboratory/storage/distribution/review practice) regulatory compliance. The costs of manufacturing and clinical development are considerable barriers. Product heterogeneity is a reality and may account for significantly different results, both in terms of safety and efficacy, as 
Table 1 Clinical trials of cell-based therapies in COVID-19 patients registered in clinicaltrials.gov

\begin{tabular}{|c|c|c|c|c|c|c|c|c|}
\hline & Title & ID & Interventions & Primary outcome & Age & Phases & Enrollment & Location \\
\hline 1 & $\begin{array}{l}\text { The Mesenchymal coviD-19 } \\
\text { Trial: a Pilot Study to Investi- } \\
\text { gate Early Efficacy of MSCs in } \\
\text { Adults With COVID-19 (MEND }\end{array}$ & NCT04537351 & CYP-001 & $\begin{array}{l}\text { Trend in trajectory of } \mathrm{PaO}_{2} / \\
\mathrm{FiO}_{2} \text { ratio ( } \mathrm{P} / \mathrm{F} \text { ratio) between } \\
\text { in } 7 \text { days }\end{array}$ & $\begin{array}{l}<18 \\
\text { years }\end{array}$ & $\begin{array}{l}\text { Phase I } \\
\text { Phase II }\end{array}$ & 24 & Australia \\
\hline 2 & $\begin{array}{l}\text { Treatment of Covid-19 Asso- } \\
\text { ciated Pneumonia with Allo- } \\
\text { genic Pooled Olfactory } \\
\text { Mucosa-derived Mesenchy- } \\
\text { mal Stem Cells }\end{array}$ & NCT04382547 & $\begin{array}{l}\text { Allogenic pooled } \\
\text { olfactory mucosa- } \\
\text { derived MSCs versus } \\
\text { control }\end{array}$ & $\begin{array}{l}\text { Treatment: Number of cured } \\
\text { patients in } 3 \text { weeks }\end{array}$ & $\begin{array}{l}18 \text { to } \\
70 \\
\text { Years }\end{array}$ & $\begin{array}{l}\text { Phase I } \\
\text { Phase II }\end{array}$ & 40 & Belarus \\
\hline 3 & $\begin{array}{l}\text { Mesenchymal Stromal Cell } \\
\text { Therapy for Severe Covid-19 } \\
\text { Infection }\end{array}$ & NCT04445454 & BM-MSC & Adverse events in 28 days & $\begin{array}{l}18 \text { to } \\
70 \\
\text { years }\end{array}$ & $\begin{array}{l}\text { Phase } 1 \\
\text { Phase } 2\end{array}$ & 20 & Belgium \\
\hline 4 & $\begin{array}{l}\text { MSC-based Therapy in } \\
\text { COVID-19-associated Acute } \\
\text { Respiratory Distress } \\
\text { Syndrome }\end{array}$ & NCT04525378 & MSCs & $\begin{array}{l}\text { Intrahospital mortality, } \\
\text { incidence of adverse events } \\
\text { in } 28 \text { days and quantification } \\
\text { of biomarkers }\end{array}$ & $\begin{array}{l}\geq 18 \\
\text { years }\end{array}$ & Phase 1 & 20 & Brazil \\
\hline 5 & $\begin{array}{l}\text { This is phase II study to } \\
\text { assess the efficacy of } \\
\text { NestaCell }{ }^{\circledast} \text { (mesenchymal } \\
\text { stem cell) to treat severe } \\
\text { COVID-19 pneumonia }\end{array}$ & NCT04315987 & $\begin{array}{l}\text { NestaCellø (MSCs) } \\
\text { versus Placebo }\end{array}$ & $\begin{array}{l}\text { Change in clinical condition } \\
\text { in } 10 \text { days }\end{array}$ & $\begin{array}{l}\geq 18 \\
\text { years }\end{array}$ & Phase II & 90 & Brazil \\
\hline 6 & $\begin{array}{l}\text { Safety and Feasibility of } \\
\text { Allogenic MSC in the } \\
\text { Treatment of COVID-19 }\end{array}$ & NCT04467047 & MSCs & Overall survival in 60 days & $\begin{array}{l}\text { Child, } \\
\text { Adult, } \\
\text { Older } \\
\text { Adult }\end{array}$ & Phase I & 10 & Brazil \\
\hline 7 & $\begin{array}{l}\text { Cellular Immuno-Therapy for } \\
\text { COVID-19 Acute Respiratory } \\
\text { Distress Syndrome - Van- } \\
\text { guard (CIRCA-19) }\end{array}$ & NCT04400032 & BMCs & $\begin{array}{l}\text { Number of Participants with } \\
\text { Treatment-Related Adverse } \\
\text { Events as Assessed by CTCAE } \\
\text { v4.0 to determine the max- } \\
\text { imum feasible tolerated dose } \\
\text { (MFTD) of BM-MSCs given to } \\
\text { patients with COVID-19 }\end{array}$ & $\begin{array}{l}\geq 18 \\
\text { years }\end{array}$ & Phase I & 9 & Canada \\
\hline 8 & $\begin{array}{l}\text { Safety and Efficacy of } \\
\text { Mesenchymal Stem Cells in } \\
\text { the Management of Severe } \\
\text { COVID-19 Pneumonia }\end{array}$ & NCT04429763 & $\begin{array}{l}\text { UC-MSCs versus } \\
\text { Placebo }\end{array}$ & $\begin{array}{l}\text { Clinical deterioration or death } \\
\text { in } 4 \text { weeks }\end{array}$ & $\begin{array}{l}18 \text { to } \\
79 \\
\text { Years }\end{array}$ & Phase II & 30 & Colombia \\
\hline 9 & $\begin{array}{l}\text { Safety and Efficacy of } \\
\text { Intravenous Wharton's Jelly } \\
\text { Derived Mesenchymal Stem } \\
\text { Cells in Acute Respiratory } \\
\text { Distress Syndrome Due to } \\
\text { COVID } 19\end{array}$ & NCT04390152 & $\begin{array}{l}\text { WJ-MSC versus } \\
\text { control }\end{array}$ & $\begin{array}{l}\text { Evaluation of efficacy of WJ- } \\
\text { MSC defined by mortality at } \\
28 \text { days of application }\end{array}$ & $\begin{array}{l}18 \text { to } \\
80 \\
\text { years }\end{array}$ & $\begin{array}{l}\text { Phase I } \\
\text { Phase II }\end{array}$ & 40 & Colombia \\
\hline 10 & $\begin{array}{l}\text { Mesenchymal Stem Cell } \\
\text { Treatment for Pneumonia } \\
\text { Patients Infected With } \\
\text { COVID-19 }\end{array}$ & NCT04252118 & MSCs & $\begin{array}{l}\text { Size of lesion area by chest } \\
\text { radiograph or } C T \text { and side } \\
\text { effects in } 28 \text { days }\end{array}$ & $\begin{array}{l}18 \text { to } \\
70 \\
\text { years }\end{array}$ & Phase 1 & 20 & China \\
\hline 11 & $\begin{array}{l}\text { Clinical Research of Human } \\
\text { Mesenchymal Stem Cells in } \\
\text { the Treatment of COVID-19 } \\
\text { Pneumonia }\end{array}$ & NCT04339660 & $\begin{array}{l}\text { UC-MSCs versus } \\
\text { Placebo }\end{array}$ & $\begin{array}{l}\text { Immune function and blood } \\
\text { oxygen saturation }\end{array}$ & $\begin{array}{l}18 \text { to } \\
75 \\
\text { years }\end{array}$ & $\begin{array}{l}\text { Phase } 1 \\
\text { Phase } 2\end{array}$ & 30 & China \\
\hline 12 & $\begin{array}{l}\text { Safety and Effectiveness of } \\
\text { Mesenchymal Stem Cells in } \\
\text { the Treatment of Pneumonia } \\
\text { of Coronavirus Disease } 2019\end{array}$ & NCT04371601 & MSCs versus control & $\begin{array}{l}\text { Improvement of pulmonary } \\
\text { function in } 12 \text { months }\end{array}$ & $\begin{array}{l}18 \text { to } \\
70 \\
\text { years }\end{array}$ & Phase I & 60 & China \\
\hline 13 & $\begin{array}{l}\text { Safety and Efficacy Study of } \\
\text { Allogeneic Human Dental } \\
\text { Pulp Mesenchymal Stem } \\
\text { Cells to Treat Severe COVID- } \\
19 \text { Patients }\end{array}$ & NCT04336254 & DPSCs versus Placebo & $\begin{array}{l}\text { Clinical improvement in } 28 \\
\text { days }\end{array}$ & $\begin{array}{l}18 \text { to } \\
65 \\
\text { years }\end{array}$ & $\begin{array}{l}\text { Phase } 1 \\
\text { Phase } 2\end{array}$ & 20 & China \\
\hline 14 & $\begin{array}{l}\text { Study of Human Umbilical } \\
\text { Cord Mesenchymal Stem }\end{array}$ & NCT04273646 & $\begin{array}{l}\text { UC-MSCs versus } \\
\text { Placebo }\end{array}$ & $\begin{array}{l}\text { Evaluation of pneumonia } \\
\text { improvement }\end{array}$ & $\begin{array}{l}18 \text { to } \\
65\end{array}$ & $\begin{array}{l}\text { Not } \\
\text { Applicable }\end{array}$ & 48 & China \\
\hline
\end{tabular}


Table 1 Clinical trials of cell-based therapies in COVID-19 patients registered in clinicaltrials.gov (Continued)

\begin{tabular}{|c|c|c|c|c|c|c|c|c|}
\hline & Title & ID & Interventions & Primary outcome & Age & Phases & Enrollment & Location \\
\hline & $\begin{array}{l}\text { Cells in the Treatment of } \\
\text { Severe COVID-19 }\end{array}$ & & & & years & & & \\
\hline 15 & $\begin{array}{l}\text { Bone Marrow-Derived Mes- } \\
\text { enchymal Stem Cell Treat- } \\
\text { ment for Severe Patients with } \\
\text { Coronavirus Disease } 2019 \\
\text { (COVID-19) }\end{array}$ & NCT04346368 & $\begin{array}{l}\text { BM-MSCs versus } \\
\text { Placebo }\end{array}$ & $\begin{array}{l}\text { Changes of oxygenation } \\
\text { index }\left(\mathrm{PaO}_{2} / \mathrm{FiO}_{2}\right) \text { at baseline, } \\
\text { 6-hour, day } 1 \text {, day } 3 \text { week } 1 \text {, } \\
\text { week } 2 \text {, week } 4 \text {, month } 6 \\
\text { Evaluation of pneumonia } \\
\text { improvement }\end{array}$ & $\begin{array}{l}18 \text { to } \\
75 \\
\text { years }\end{array}$ & $\begin{array}{l}\text { Phase I } \\
\text { Phase II }\end{array}$ & 20 & China \\
\hline 16 & $\begin{array}{l}\text { Pilot Clinical Study on } \\
\text { Inhalation of Mesenchymal } \\
\text { Stem Cells Exosomes } \\
\text { Treating Severe Novel } \\
\text { Coronavirus Pneumonia }\end{array}$ & NCT04276987 & MSCs-Exo & $\begin{array}{l}\text { Safety evaluation within } 28 \\
\text { days after first treatment, } \\
\text { including frequency of } \\
\text { adverse reaction (AE) and } \\
\text { severe adverse reaction (SAE) }\end{array}$ & $\begin{array}{l}18 \text { to } \\
75 \\
\text { years }\end{array}$ & Phase I & 24 & China \\
\hline 15 & $\begin{array}{l}\text { Novel Coronavirus Induced } \\
\text { Severe Pneumonia Treated } \\
\text { by Dental Pulp Mesenchymal } \\
\text { Stem Cells }\end{array}$ & NCT04302519 & Dental pulp MSCs & $\begin{array}{l}\text { Disappear time of ground- } \\
\text { glass shadow in the lungs in } \\
14 \text { days }\end{array}$ & $\begin{array}{l}18 \text { to } \\
75 \\
\text { years }\end{array}$ & Phase I & 24 & China \\
\hline 16 & $\begin{array}{l}\text { Umbilical Cord (UC)-Derived } \\
\text { Mesenchymal Stem Cells } \\
\text { (MSCs) Treatment for the } \\
\text { 2019-novel Coronavirus } \\
\text { (nCOV) Pneumonia }\end{array}$ & NCT04269525 & UC-MSCS & $\begin{array}{l}\text { Oxygenation index on after } \\
14 \text { days }\end{array}$ & $\begin{array}{l}18 \text { to } \\
80 \\
\text { years }\end{array}$ & Phase ॥ & 16 & China \\
\hline 17 & $\begin{array}{l}\text { Treatment with Human } \\
\text { Umbilical Cord-derived Mes- } \\
\text { enchymal Stem Cells for Se- } \\
\text { vere Corona Virus Disease } \\
2019 \text { (COVID-19) }\end{array}$ & NCT04288102 & $\begin{array}{l}\text { UC-MSCs versus } \\
\text { Placebo }\end{array}$ & $\begin{array}{l}\text { Change in lesion proportion } \\
\text { (\%) of full lung volume from } \\
\text { baseline to day } 28 \\
\text { Evaluation of pneumonia } \\
\text { improvement }\end{array}$ & $\begin{array}{l}18 \text { to } \\
75 \\
\text { years }\end{array}$ & Phase II & 100 & China \\
\hline 18 & $\begin{array}{l}\text { Cell Therapy Using Umbilical } \\
\text { Cord-derived Mesenchymal } \\
\text { Stromal Cells in SARS-CoV-2- } \\
\text { related ARDS }\end{array}$ & NCT04333368 & $\begin{array}{l}\text { UC-MSC versus } \mathrm{NaCl} \\
0.9 \%\end{array}$ & $\begin{array}{l}\mathrm{PaO}_{2} / \mathrm{FiO}_{2} \text { ratio from baseline } \\
\text { to day } 7\end{array}$ & $\begin{array}{l}\geq 18 \\
\text { years }\end{array}$ & $\begin{array}{l}\text { Phase } 1 \\
\text { Phase } 2\end{array}$ & 40 & France \\
\hline 19 & $\begin{array}{l}\text { Mesenchymal Stem Cells } \\
\text { (MSCs) in Inflammation- } \\
\text { Resolution Programs of Cor- } \\
\text { onavirus Disease } 2019 \\
\text { (COVID-19) Induced Acute } \\
\text { Respiratory Distress Syn- } \\
\text { drome (ARDS) }\end{array}$ & NCT04377334 & $\begin{array}{l}\text { BM-MSCs versus } \\
\text { control }\end{array}$ & $\begin{array}{l}\text { Lung injury score in } 10 \text { days } \\
\text { Improvement of lung injury } \\
\text { score (LIS), 0-16 points, sever- } \\
\text { ity increasing with higher } \\
\text { points }\end{array}$ & $\begin{array}{l}\geq 18 \\
\text { years }\end{array}$ & Phase II & 40 & Germany \\
\hline 20 & $\begin{array}{l}\text { Administration of Allogenic } \\
\text { UC-MSCs as Adjuvant Ther- } \\
\text { apy for Critically-III COVID-19 } \\
\text { Patients }\end{array}$ & NCT04457609 & $\begin{array}{l}\text { UC-MSCS versus } \\
\text { control group }\end{array}$ & $\begin{array}{l}\text { Clinical improvement in } 15 \\
\text { days }\end{array}$ & $\begin{array}{l}18 \text { to } \\
95 \\
\text { years }\end{array}$ & Phase I & 40 & Indonesia \\
\hline 21 & $\begin{array}{l}\text { Treatment of Severe COVID- } \\
19 \text { Patients using Secretome } \\
\text { of Hypoxia-Mesenchymal } \\
\text { Stem Cells in Indonesia }\end{array}$ & NCT04753476 & $\begin{array}{l}\text { S-MSCs versus } \\
\text { control }\end{array}$ & $\begin{array}{l}\text { Change in patients clinical } \\
\text { manifestation in } 1 \text { months } \\
\text { (mild, moderate, or severe) }\end{array}$ & $\begin{array}{l}\text { Child, } \\
\text { Adult, } \\
\text { Older } \\
\text { Adult }\end{array}$ & Phase II & 48 & Indonesia \\
\hline 22 & $\begin{array}{l}\text { Therapeutic Study to } \\
\text { Evaluate the Safety and } \\
\text { Efficacy of DW-MSC in } \\
\text { COVID-19 Patients (DW-MSC) }\end{array}$ & NCT04535856 & MSCs versus Placebo & $\begin{array}{l}\text { Treatment-emergent adverse } \\
\text { event All adverse reactions in } \\
\text { treatment group in } 28 \text { days }\end{array}$ & $\begin{array}{l}\geq 19 \\
\text { years }\end{array}$ & Phase I & 9 & Indonesia \\
\hline 23 & $\begin{array}{l}\text { Mesenchymal Stem Cell } \\
\text { Therapy for SARS-CoV-2-re- } \\
\text { lated ARDS }\end{array}$ & NCT04366063 & MSCs and EVs & $\begin{array}{l}\text { Adverse events in } 28 \text { days } \\
\text { and blood oxygen saturation }\end{array}$ & $\begin{array}{l}18 \text { to } \\
65 \\
\text { years }\end{array}$ & $\begin{array}{l}\text { Phase } 2 \\
\text { Phase } 3\end{array}$ & 60 & Iran \\
\hline 24 & $\begin{array}{l}\text { An Exploratory Study of ADR- } \\
001 \text { in Patients with Severe } \\
\text { Pneumonia Caused by SARS- } \\
\text { CoV-2 Infection (COVID-19) }\end{array}$ & NCT04522986 & MSCs & $\begin{array}{l}\text { Safety: adverse event in } 12 \\
\text { weeks }\end{array}$ & $\begin{array}{l}\geq 20 \\
\text { years }\end{array}$ & Phase I & 6 & Japan \\
\hline 25 & $\begin{array}{l}\text { Mesenchymal Stem Cell for } \\
\text { Acute Respiratory Distress } \\
\text { Syndrome Due for COVID-19 }\end{array}$ & NCT04416139 & UC-MSCS & $\begin{array}{l}\mathrm{PaO}_{2} / \mathrm{FiO}_{2} \text { ratio and clinical } \\
\text { changes in } 3 \text { weeks }\end{array}$ & $\begin{array}{l}18 \\
\text { years } \\
\text { and } \\
\text { older }\end{array}$ & Phase 2 & 10 & Mexico \\
\hline
\end{tabular}


Table 1 Clinical trials of cell-based therapies in COVID-19 patients registered in clinicaltrials.gov (Continued)

\begin{tabular}{|c|c|c|c|c|c|c|c|c|}
\hline & Title & ID & Interventions & Primary outcome & Age & Phases & Enrollment & Location \\
\hline \multicolumn{9}{|l|}{26} \\
\hline 27 & $\begin{array}{l}\text { Mesenchymal Stem Cells in } \\
\text { Patients Diagnosed With } \\
\text { COVID-19 }\end{array}$ & NCT04611256 & MSCs versus control & $\begin{array}{l}\text { Change form baseline in } \\
\text { Arterial oxygen saturation up } \\
\text { to } 25 \text { days } \\
\text { Pulmonary lesion area will be } \\
\text { taken by a chest X-ray or } \\
\text { computed axial tomography }\end{array}$ & $\begin{array}{l}18 \text { to } \\
65 \\
\text { years }\end{array}$ & Phase I & 20 & Mexico \\
\hline 28 & $\begin{array}{l}\text { Use of Mesenchymal Stem } \\
\text { Cells in Acute Respiratory } \\
\text { Distress Syndrome Caused by } \\
\text { COVID-19 }\end{array}$ & NCT04456361 & WJ-MSCS & $\begin{array}{l}\text { Oxygen saturation Baseline, } \\
\text { and at days 2, } 4 \text { and } 14 \text { post- } \\
\text { treatment } \\
\text { Number of patients with } \\
\text { changes in percentage of } \\
\text { resting oxygen saturation } \\
(\% \mathrm{O})\end{array}$ & $\begin{array}{l}\geq 18 \\
\text { years }\end{array}$ & Phase I & 9 & Mexico \\
\hline 29 & $\begin{array}{l}\text { Efficacy of Intravenous } \\
\text { Infusions of Stem Cells in the } \\
\text { Treatment of COVID-19 } \\
\text { Patients }\end{array}$ & NCT04437823 & UC-MSCS & $\begin{array}{l}\text { Adverse events, } \\
\text { improvements in chest } \\
\text { radiograph or chest CT scan } \\
\text { in } 30 \text { days }\end{array}$ & $\begin{array}{l}30 \text { to } \\
70 \\
\text { years }\end{array}$ & Phase 2 & 20 & Pakistan \\
\hline 30 & $\begin{array}{l}\text { Mesenchymal Stem Cell } \\
\text { Infusion for COVID-19 } \\
\text { Infection }\end{array}$ & NCT04444271 & MSC versus Placebo & Overall survival in 30 days & $\begin{array}{l}10 \\
\text { years } \\
\text { and } \\
\text { older }\end{array}$ & Phase 2 & 20 & Pakistan \\
\hline 31 & $\begin{array}{l}\text { Investigational Treatments for } \\
\text { COVID-19 in Tertiary Care } \\
\text { Hospital of Pakistan }\end{array}$ & NCT04492501 & MSCs versus control & Survival in 28 days & $\begin{array}{l}18 \text { to } \\
90 \\
\text { years }\end{array}$ & $\begin{array}{l}\text { Not } \\
\text { Applicable }\end{array}$ & 600 & Pakistan \\
\hline 32 & $\begin{array}{l}\text { Treatment of Severe COVID- } \\
19 \text { Pneumonia with Allogen- } \\
\text { eic Mesenchymal Stromal } \\
\text { Cells (COVID_MSV) }\end{array}$ & NCT04361942 & MSC versus Placebo & $\begin{array}{l}\text { Proportion of patients who } \\
\text { have achieved withdrawal of } \\
\text { invasive mechanical } \\
\text { ventilation in } 7 \text { days and } \\
\text { mortality rate in } 28 \text { days }\end{array}$ & $\begin{array}{l}\geq 18 \\
\text { years }\end{array}$ & Phase 2 & 24 & Spain \\
\hline 33 & $\begin{array}{l}\text { Clinical Trial of Allogeneic } \\
\text { Mesenchymal Cells from } \\
\text { Umbilical Cord Tissue in } \\
\text { Patients With COVID-19 }\end{array}$ & NCT04366271 & $\begin{array}{l}\text { UC-MSC versus } \\
\text { Standard of care }\end{array}$ & Mortality rate in 28 days & $\begin{array}{l}40 \text { to } \\
80 \\
\text { years }\end{array}$ & Phase 2 & 106 & Spain \\
\hline 34 & $\begin{array}{l}\text { Clinical Trial to Assess the } \\
\text { Safety and Efficacy of } \\
\text { Intravenous Administration of } \\
\text { Allogeneic Adult } \\
\text { Mesenchymal Stem Cells of } \\
\text { Expanded Adipose Tissue in } \\
\text { Patients With Severe } \\
\text { Pneumonia Due to COVID-19 }\end{array}$ & NCT04366323 & AD-MSCS & $\begin{array}{l}\text { Adverse event rate in } 12 \\
\text { months; survival rate in } 28 \\
\text { days }\end{array}$ & $\begin{array}{l}18 \text { to } \\
80 \\
\text { years }\end{array}$ & $\begin{array}{l}\text { Phase } 1 \\
\text { Phase } 2\end{array}$ & 26 & Spain \\
\hline 35 & $\begin{array}{l}\text { BAttLe Against COVID-19 } \\
\text { Using MesenchYmal Stromal } \\
\text { Cells }\end{array}$ & NCT04348461 & $\begin{array}{l}\text { AD-MSCs versus } \\
\text { control }\end{array}$ & $\begin{array}{l}\text { Efficacy of the administration } \\
\text { of allogeneic AD- MSCs by } \\
\text { survival rate in } 28 \text { days } \\
\text { Safety of the administration } \\
\text { of allogeneic AD-MSCs by ad- } \\
\text { verse event rate in } 6 \text { months }\end{array}$ & $\begin{array}{l}\geq 18 \\
\text { years }\end{array}$ & Phase II & 100 & Spain \\
\hline 36 & $\begin{array}{l}\text { Efficacy and Safety Evaluation } \\
\text { of Mesenchymal Stem Cells } \\
\text { for the Treatment of Patients } \\
\text { with Respiratory Distress Due } \\
\text { to COVID-19 (COVIDMES) }\end{array}$ & NCT04390139 & $\begin{array}{l}\text { WJ-MSC versus } \\
\text { Placebo }\end{array}$ & All-cause mortality at day 28 & $\begin{array}{l}18 \text { to } \\
70 \\
\text { years }\end{array}$ & $\begin{array}{l}\text { Phase I } \\
\text { Phase II }\end{array}$ & 30 & Spain \\
\hline 37 & $\begin{array}{l}\text { Treatment of Severe COVID- } \\
19 \text { Pneumonia } \\
\text { with Allogeneic } \\
\text { Mesenchymal Stromal Cells } \\
\text { (COVID-MSV) }\end{array}$ & NCT04361942 & MSCs versus Placebo & $\begin{array}{l}\text { Proportion of patients who } \\
\text { have achieved withdrawal of } \\
\text { invasive mechanical } \\
\text { ventilation in } 7 \text { days }\end{array}$ & $\begin{array}{l}\geq 18 \\
\text { years }\end{array}$ & Phase II & 24 & Spain \\
\hline 38 & $\begin{array}{l}\text { Mesenchymal Stromal Cell } \\
\text { Therapy for The Treatment of } \\
\text { Acute Respiratory Distress }\end{array}$ & NCT04447833 & BM-MSC & $\begin{array}{l}\text { Incidence of pre-specified ad- } \\
\text { verse events in } 10 \text { days }\end{array}$ & $\begin{array}{l}18 \text { to } \\
65 \\
\text { years }\end{array}$ & Phase 1 & 9 & Sweden \\
\hline
\end{tabular}
Syndrome 
Table 1 Clinical trials of cell-based therapies in COVID-19 patients registered in clinicaltrials.gov (Continued)

\begin{tabular}{|c|c|c|c|c|c|c|c|c|}
\hline & Title & ID & Interventions & Primary outcome & Age & Phases & Enrollment & Location \\
\hline 39 & $\begin{array}{l}\text { Investigational Treatments for } \\
\text { COVID-19 in Tertiary Care } \\
\text { Hospital of Pakistan }\end{array}$ & NCT04492501 & MSCs versus control & Survival in 28 days & $\begin{array}{l}18 \text { to } \\
90 \\
\text { years }\end{array}$ & & 600 & $\overline{\text { Pakistan }}$ \\
\hline 40 & $\begin{array}{l}\text { Evaluation of Safety and } \\
\text { Efficiency of Method of } \\
\text { Exosome Inhalation in SARS- } \\
\text { CoV-2 Associated Pneumonia }\end{array}$ & NCT04491240 & $\begin{array}{l}\text { EXO 1, EXO } 2 \text { versus } \\
\text { Placebo }\end{array}$ & $\begin{array}{l}\text { Number of participants with } \\
\text { non-serious and serious ad- } \\
\text { verse events during trial } 30 \\
\text { days after clinic discharge } \\
\text { Number of participants with } \\
\text { non-serious and serious ad- } \\
\text { verse during inhalation pro- } \\
\text { cedure after each inhalation } \\
\text { during } 10 \text { days }\end{array}$ & $\begin{array}{l}18 \text { to } \\
65 \\
\text { years }\end{array}$ & $\begin{array}{l}\text { Phase I } \\
\text { Phase II }\end{array}$ & 30 & Russian \\
\hline 41 & $\begin{array}{l}\text { Safety and Efficiency of } \\
\text { Method of Exosome } \\
\text { Inhalation in COVID-19 Asso- } \\
\text { ciated Pneumonia }\end{array}$ & NCT04602442 & $\begin{array}{l}\text { EXO 1, EXO } 2 \text { versus } \\
\text { Placebo }\end{array}$ & $\begin{array}{l}\text { Number of participants with } \\
\text { non-serious and serious ad- } \\
\text { verse events during trial in } 2 \\
\text { months } \\
\text { Number of participants with } \\
\text { non-serious and serious ad- } \\
\text { verse during inhalation pro- } \\
\text { cedure in } 10 \text { days during } \\
\text { inhalation procedures }\end{array}$ & $\begin{array}{l}18 \text { to } \\
65 \\
\text { years }\end{array}$ & Phase II & 90 & Russian \\
\hline 42 & $\begin{array}{l}\text { Clinical Use of Stem Cells for } \\
\text { the Treatment of Covid-19 }\end{array}$ & NCT04392778 & MSC versus control & $\begin{array}{l}\text { Clinical improvement in } 3 \\
\text { months }\end{array}$ & $\begin{array}{l}40 \text { to } \\
60 \\
\text { years }\end{array}$ & $\begin{array}{l}\text { Phase } 1 \\
\text { Phase } 2\end{array}$ & 30 & Turkey \\
\hline 43 & $\begin{array}{l}\text { Mesenchymal Stem Cells } \\
\text { Therapy in Patients With } \\
\text { COVID-19 Pneumonia }\end{array}$ & NCT04713878 & MSCs & $\begin{array}{l}\text { Clinical symptoms as } \\
\text { respiratory distress }\end{array}$ & $\begin{array}{l}18 \text { to } \\
90 \\
\text { years }\end{array}$ & $\begin{array}{l}\text { Not } \\
\text { Applicable }\end{array}$ & 21 & Turkey \\
\hline 44 & $\begin{array}{l}\text { Repair of Acute Respiratory } \\
\text { Distress Syndrome by } \\
\text { Stromal Cell Administration } \\
\text { (REALIST) (COVID-19) }\end{array}$ & NCT03042143 & $\begin{array}{l}\text { UC-MSCs versus } \\
\text { Plasma-Lyte }\end{array}$ & $\begin{array}{l}\text { Oxygenation index in } 7 \text { days } \\
\text { and incidence of serious } \\
\text { adverse events in } 28 \text { days }\end{array}$ & $\begin{array}{l}\geq 16 \\
\text { years }\end{array}$ & $\begin{array}{l}\text { Phase } 1 \\
\text { Phase } 2\end{array}$ & 75 & $\begin{array}{l}\text { United } \\
\text { Kingdom }\end{array}$ \\
\hline 45 & $\begin{array}{l}\text { Treatment of Coronavirus } \\
\text { COVID-19 Pneumonia (Patho- } \\
\text { gen SARS-CoV-2) with Cryo- } \\
\text { preserved Allogeneic P_- } \\
\text { MMSCs and UC-MMSCs }\end{array}$ & NCT04461925 & $\begin{array}{l}\text { P-MMSCs versus } \\
\text { Antibiotics/ } \\
\text { Hormones/ } \\
\text { Anticoagulant } \\
\text { Therapy }\end{array}$ & $\begin{array}{l}\mathrm{PaO}_{2} / \mathrm{FiO}_{2} \text { ratio and mortality } \\
\text { rate in } 28 \text { days }\end{array}$ & $\begin{array}{l}18 \text { to } \\
75 \\
\text { years }\end{array}$ & $\begin{array}{l}\text { Phase } 1 \\
\text { Phase } 2\end{array}$ & 30 & Ukraine \\
\hline 46 & $\begin{array}{l}\text { Use of UC-MSCs for COVID- } \\
19 \text { Patients }\end{array}$ & NCT04355728 & $\begin{array}{l}\text { UC-MSCs + Heparin } \\
\text { alongside best } \\
\text { supportive care } \\
\text { versus Vehicle }+ \\
\text { Heparin alongside } \\
\text { best supportive care }\end{array}$ & $\begin{array}{l}\text { Incidence of pre-specified } \\
\text { infusion-associated adverse } \\
\text { events in } 5 \text { days and inci- } \\
\text { dence of severe adverse } \\
\text { events in } 90 \text { days }\end{array}$ & $\begin{array}{l}\geq 18 \\
\text { years }\end{array}$ & $\begin{array}{l}\text { Phase } 1 \\
\text { Phase } 2\end{array}$ & 24 & $\begin{array}{l}\text { United } \\
\text { States }\end{array}$ \\
\hline 47 & $\begin{array}{l}\text { hCT-MSCs for COVID-19 } \\
\text { ARDS }\end{array}$ & NCT04399889 & $\begin{array}{l}\text { UC-MSCS versus } \\
\text { Standard care }\end{array}$ & $\begin{array}{l}\text { Safety of the investigational } \\
\text { product in } 28 \text { days }\end{array}$ & $\begin{array}{l}\geq 18 \\
\text { years }\end{array}$ & $\begin{array}{l}\text { Phase } 1 \\
\text { Phase } 2\end{array}$ & 30 & $\begin{array}{l}\text { United } \\
\text { States }\end{array}$ \\
\hline 48 & $\begin{array}{l}\text { Umbilical Cord Lining Stem } \\
\text { Cells (ULSC) in Patients With } \\
\text { COVID-19 ARDS (ULSC) }\end{array}$ & NCT04494386 & $\begin{array}{l}\text { UC-MSCs versus } \\
\text { Placebo }\end{array}$ & $\begin{array}{l}\text { Incidence of dose-limiting } \\
\text { toxicity and adverse events in } \\
12 \text { months }\end{array}$ & $\begin{array}{l}\geq 18 \\
\text { years }\end{array}$ & $\begin{array}{l}\text { Phase } 1 \\
\text { Phase } 2\end{array}$ & 60 & $\begin{array}{l}\text { United } \\
\text { States }\end{array}$ \\
\hline 49 & $\begin{array}{l}\text { Cord Blood-Derived Mesen- } \\
\text { chymal Stem Cells for the } \\
\text { Treatment of COVID-19 Re- } \\
\text { lated Acute Respiratory Dis- } \\
\text { tress Syndrome }\end{array}$ & NCT04565665 & CB-MSC & $\begin{array}{l}\text { Incidence of serious adverse } \\
\text { events }\end{array}$ & $\begin{array}{l}\geq 18 \\
\text { years }\end{array}$ & Phase II & 70 & $\begin{array}{l}\text { United } \\
\text { States }\end{array}$ \\
\hline 50 & $\begin{array}{l}\text { Study of Intravenous } \\
\text { Administration of Allogeneic } \\
\text { Adipose-Derived Mesenchy- } \\
\text { mal Stem Cells for COVID-19- } \\
\text { Induced Acute Respiratory } \\
\text { Distress }\end{array}$ & NCT04728698 & $\begin{array}{l}\text { COVI-MSCs versus } \\
\text { Placebo }\end{array}$ & Mortality at day 28 & $\begin{array}{l}\geq 18 \\
\text { years }\end{array}$ & Phase II & 100 & $\begin{array}{l}\text { United } \\
\text { States }\end{array}$ \\
\hline 51 & $\begin{array}{l}\text { A Randomized, Double-Blind, } \\
\text { Placebo-Controlled Clinical } \\
\text { Trial to Determine the Safety } \\
\text { and Efficacy of Hope }\end{array}$ & NCT04348435 & $\begin{array}{l}\text { HB-adMSCs versus } \\
\text { Placebos }\end{array}$ & $\begin{array}{l}\text { Incidence of hospitalization } \\
\text { for COVID-19 (week } 0 \\
\text { through week } 26 \text { end of } \\
\text { study }\end{array}$ & $\begin{array}{l}\geq 18 \\
\text { years }\end{array}$ & Phase II & 100 & $\begin{array}{l}\text { United } \\
\text { States }\end{array}$ \\
\hline
\end{tabular}


Table 1 Clinical trials of cell-based therapies in COVID-19 patients registered in clinicaltrials.gov (Continued)

\begin{tabular}{|c|c|c|c|c|c|c|c|c|}
\hline & Title & ID & Interventions & Primary outcome & Age & Phases & Enrollment & Location \\
\hline & $\begin{array}{l}\text { Biosciences Allogeneic Mes- } \\
\text { enchymal Stem Cell Therapy } \\
\text { (HB-adMSCs) to Provide Pro- } \\
\text { tection Against COVID-19 }\end{array}$ & & & $\begin{array}{l}\text { Number of subjects that } \\
\text { must be hospitalized for } \\
\text { COVID-19 during the conduct } \\
\text { of this study }\end{array}$ & & & & \\
\hline 52 & $\begin{array}{l}\text { Regenerative Medicine for } \\
\text { COVID-19 and Flu-Elicited } \\
\text { ARDS Using Longeveron } \\
\text { Mesenchymal Stem Cells } \\
\text { (LMSCs) }\end{array}$ & NCT04629105 & $\begin{array}{l}\text { LMSCs versus } \\
\text { Placebo }\end{array}$ & $\begin{array}{l}\text { Incidence of treatment- } \\
\text { emergent serious adverse } \\
\text { events (TE-SAEs) within } 4 \\
\text { weeks after treatment }\end{array}$ & $\begin{array}{l}\geq 18 \\
\text { years }\end{array}$ & Phase I & 70 & $\begin{array}{l}\text { United } \\
\text { States }\end{array}$ \\
\hline 53 & $\begin{array}{l}\text { A Clinical Trial to Determine } \\
\text { the Safety and Efficacy of } \\
\text { Hope Biosciences } \\
\text { Autologous Mesenchymal } \\
\text { Stem Cell Therapy (HB- } \\
\text { adMSCs) to Provide } \\
\text { Protection Against COVID-19 }\end{array}$ & NCT04349631 & HB-adMSCs & $\begin{array}{l}\text { Number of subjects that } \\
\text { require hospitalization for } \\
\text { COVID-19 }\end{array}$ & $\begin{array}{l}\geq 65 \\
\text { years }\end{array}$ & Phase II & 56 & $\begin{array}{l}\text { United } \\
\text { States }\end{array}$ \\
\hline 54 & $\begin{array}{l}\text { Efficacy and Safety Study of } \\
\text { Allogeneic HB-adMSCs for } \\
\text { the Treatment of COVID-19 }\end{array}$ & NCT04362189 & $\begin{array}{l}\text { HB-adMSC versus } \\
\text { placebo }\end{array}$ & $\begin{array}{l}\text { Interleukin-6, C-reactive pro- } \\
\text { tein, oxygenation, NF alpha, } \\
\text { IL-10 from change from base- } \\
\text { line and time to return to } \\
\text { room air }\end{array}$ & $\begin{array}{l}\geq 18 \\
\text { years }\end{array}$ & Phase II & 100 & $\begin{array}{l}\text { United } \\
\text { States }\end{array}$ \\
\hline 55 & $\begin{array}{l}\text { Umbilical Cord Tissue (UC) } \\
\text { Derived Mesenchymal Stem } \\
\text { Cells (MSCS) Versus Placebo } \\
\text { to Treat Acute Pulmonary } \\
\text { Inflammation Due to COVID- } \\
19\end{array}$ & NCT04490486 & $\begin{array}{l}\text { UC-MSCs } \\
\text { versus Placebo }\end{array}$ & $\begin{array}{l}\text { Safety of UCMSCS will be } \\
\text { reported as the percentage } \\
\text { of participants in each } \\
\text { treatment group that } \\
\text { experienced a treatment- } \\
\text { related serious adverse } \\
\text { events (SAEs) }\end{array}$ & $\begin{array}{l}\geq 18 \\
\text { years }\end{array}$ & Phase I & 21 & $\begin{array}{l}\text { United } \\
\text { States }\end{array}$ \\
\hline 56 & $\begin{array}{l}\text { A Phase II Study in Patients } \\
\text { with Moderate to Severe } \\
\text { ARDS Due to COVID-19 }\end{array}$ & NCT04780685 & $\begin{array}{l}\text { hMSCs versus } \\
\text { placebo }\end{array}$ & $\begin{array}{l}\text { Survival in } 14 \text { days post- } \\
\text { treatment }\end{array}$ & $\begin{array}{l}\geq 18 \\
\text { years }\end{array}$ & Phase II & 40 & $\begin{array}{l}\text { United } \\
\text { States }\end{array}$ \\
\hline 57 & $\begin{array}{l}\text { ACT-20 in Patients with } \\
\text { Severe COVID-19 Pneumonia }\end{array}$ & NCT04398303 & $\begin{array}{l}\text { CT-20-MSC, or ACT- } \\
20-C M \text { versus } \\
\text { Placebo }\end{array}$ & $\begin{array}{l}\text { Mortality day } 30 \text { post- } \\
\text { treatment }\end{array}$ & $\begin{array}{l}18 \text { to } \\
85 \\
\text { years }\end{array}$ & $\begin{array}{l}\text { Phase I } \\
\text { Phase II }\end{array}$ & 70 & $\begin{array}{l}\text { United } \\
\text { States }\end{array}$ \\
\hline 58 & MSCs in COVID-19 ARDS & NCT04371393 & $\begin{array}{l}\text { Remestemcel-L } \\
\text { versus Placebo }\end{array}$ & $\begin{array}{l}\text { Number of all-cause mortality } \\
\text { within } 30 \text { days of } \\
\text { randomization } \\
\text { Change in IL6, IL-8, TNF-alpha } \\
\text { inflammatory marker level in } \\
7,14,21,30 \text { days }\end{array}$ & $\begin{array}{l}18 \text { to } \\
75 \\
\text { years }\end{array}$ & Phase III & 223 & $\begin{array}{l}\text { United } \\
\text { States }\end{array}$ \\
\hline 59 & $\begin{array}{l}\text { Multiple Dosing of } \\
\text { Mesenchymal Stromal Cells } \\
\text { in Patients with ARDS } \\
\text { (COVID-19) }\end{array}$ & NCT04466098 & MSCs versus Placebo & $\begin{array}{l}\text { Incidence of grade } 3-5 \\
\text { infusional toxicities and } \\
\text { predefined hemodynamic or } \\
\text { respiratory adverse events } \\
\text { related to the infusion of } \\
\text { MSC in } 6 \text { hours of the start of } \\
\text { the infusion }\end{array}$ & $\begin{array}{l}18 \text { to } \\
80 \\
\text { years }\end{array}$ & Phase II & 30 & $\begin{array}{l}\text { United } \\
\text { States }\end{array}$ \\
\hline 60 & $\begin{array}{l}\text { A Study of Cell Therapy in } \\
\text { COVID-19 Subjects with } \\
\text { Acute Kidney Injury Who Are } \\
\text { Receiving Renal Replacement } \\
\text { Therapy }\end{array}$ & NCT04445220 & $\begin{array}{l}\text { SBI-101 versus } \\
\text { control }\end{array}$ & $\begin{array}{l}\text { Safety and tolerability as } \\
\text { measured by incidence of IP- } \\
\text { related serious adverse } \\
\text { events in } 180\end{array}$ & $\begin{array}{l}\geq 18 \\
\text { years }\end{array}$ & $\begin{array}{l}\text { Phase I } \\
\text { Phase II }\end{array}$ & 22 & $\begin{array}{l}\text { United } \\
\text { States }\end{array}$ \\
\hline 61 & $\begin{array}{l}\text { Study of Descartes-30 in } \\
\text { Acute Respiratory Distress } \\
\text { Syndrome }\end{array}$ & NCT04524962 & Descartes 30 & $\begin{array}{l}\text { To assess the safety of } \\
\text { Descartes-30 in patients with } \\
\text { moderate-to-severe ARDS in } \\
2 \text { years }\end{array}$ & $\begin{array}{l}\geq 18 \\
\text { years }\end{array}$ & $\begin{array}{l}\text { Phase I } \\
\text { Phase II }\end{array}$ & 30 & $\begin{array}{l}\text { United } \\
\text { States }\end{array}$ \\
\hline 62 & $\begin{array}{l}\text { Mesenchymal Stem Cells for } \\
\text { the Treatment of COVID-19 }\end{array}$ & NCT04573270 & $\begin{array}{l}\text { Primepro versus } \\
\text { Placebo }\end{array}$ & $\begin{array}{l}\text { Survival rate in COVID-19 in- } \\
\text { fected patients admitted to } \\
\text { hospital for complications } \\
\text { Contraction rate of COVID-19 } \\
\text { in healthy healthcare workers } \\
\text { following patients admitted }\end{array}$ & $\begin{array}{l}\geq 18 \\
\text { years }\end{array}$ & Phase I & 40 & $\begin{array}{l}\text { United } \\
\text { States }\end{array}$ \\
\hline
\end{tabular}


Table 1 Clinical trials of cell-based therapies in COVID-19 patients registered in clinicaltrials.gov (Continued)

\begin{tabular}{|c|c|c|c|c|c|c|c|c|}
\hline & Title & ID & Interventions & Primary outcome & Age & Phases & Enrollment & Location \\
\hline & & & & $\begin{array}{l}\text { to hospital for complications } \\
\text { due to COVID-19 }\end{array}$ & & & & \\
\hline 63 & $\begin{array}{l}\text { Mesenchymal Stromal Cells } \\
\text { for the Treatment of SARS- } \\
\text { CoV-2 Induced Acute Respira- } \\
\text { tory Failure (COVID-19 } \\
\text { Disease) }\end{array}$ & NCT04362189 & MSCs versus control & $\begin{array}{l}\text { Treatment-related serious } \\
\text { adverse events (tSAEs) } 28 \\
\text { days post cell infusion and } \\
\text { Change in clinical status in } \\
14 \text { days post infusion }\end{array}$ & $\begin{array}{l}\geq 18 \\
\text { years }\end{array}$ & $\begin{array}{l}\text { Phase I } \\
\text { Phase II }\end{array}$ & 30 & $\begin{array}{l}\text { United } \\
\text { State }\end{array}$ \\
\hline 64 & $\begin{array}{l}\text { Study of the Safety of } \\
\text { Therapeutic Tx With } \\
\text { Immunomodulatory MSC in } \\
\text { Adults With COVID-19 Infec- } \\
\text { tion Requiring Mechanical } \\
\text { Ventilation }\end{array}$ & NCT04397796 & $\begin{array}{l}\text { BM-Allo.MSC versus } \\
\text { Placebo }\end{array}$ & $\begin{array}{l}\text { Incidence of AEs, mortality, } \\
\text { death, within } 30 \text { days of } \\
\text { randomization } \\
\text { Number of ventilator-free } \\
\text { days in } 60 \text { days }\end{array}$ & $\begin{array}{l}\geq 18 \\
\text { years }\end{array}$ & Phase I & 45 & $\begin{array}{l}\text { United } \\
\text { States }\end{array}$ \\
\hline 65 & $\begin{array}{l}\text { The Use of Exosomes for the } \\
\text { Treatment of Acute } \\
\text { Respiratory Distress } \\
\text { Syndrome or Novel } \\
\text { Coronavirus Pneumonia } \\
\text { Caused by COVID-19 } \\
\text { (ARDOXSO) }\end{array}$ & NCT04798716 & MSC-ExO & $\begin{array}{l}\text { Evaluate the efficacy of } \\
\text { ARDOXSO }^{\text {TM }} \text { as an } \\
\text { interventional exosome } \\
\text { therapy in COVID-19 patients } \\
\text { in } 90 \text { days }\end{array}$ & $\begin{array}{l}\geq 18 \\
\text { years }\end{array}$ & $\begin{array}{l}\text { Phase I } \\
\text { Phase II }\end{array}$ & 55 & $\begin{array}{l}\text { United } \\
\text { States }\end{array}$ \\
\hline 66 & $\begin{array}{l}\text { Adipose Mesenchymal Cells } \\
\text { for Abatement of SARS-CoV-2 } \\
\text { Respiratory Compromise in } \\
\text { COVID-19 Disease }\end{array}$ & NCT04352803 & AD-MSCs & $\begin{array}{l}\text { Safety } \\
\text { Incidence of unexpected } \\
\text { adverse events within } 28 \\
\text { days following IV } \\
\text { administration of MSCs and } \\
\text { efficacy }\end{array}$ & $\begin{array}{l}18 \text { to } \\
90 \\
\text { Years }\end{array}$ & Phase I & 20 & $\begin{array}{l}\text { United } \\
\text { States }\end{array}$ \\
\hline 67 & $\begin{array}{l}\text { Use of hUC-MSC Product } \\
\text { (BX-U001) for the Treatment } \\
\text { of COVID-19 With ARDS }\end{array}$ & NCT04452097 & $\begin{array}{l}\text { HU-MSCs versus } \\
\text { Placebo }\end{array}$ & $\begin{array}{l}\text { Incidence of infusion-related } \\
\text { adverse events in day } 3 \\
\text { Incidence of any treatment- } \\
\text { emergent adverse events } \\
\text { (TEAEs) and treatment- } \\
\text { emergent serious adverse } \\
\text { events (TE-SAEs) in day } 28\end{array}$ & $\begin{array}{l}18 \text { to } \\
80 \\
\text { years }\end{array}$ & $\begin{array}{l}\text { Phase I } \\
\text { Phase II }\end{array}$ & 39 & $\begin{array}{l}\text { United } \\
\text { States }\end{array}$ \\
\hline
\end{tabular}

MSCs, mesenchymal stem/stromal cells; BM-MSCs, bone marrow-derived mesenchymal stem cells; UC-MSCs, umbilical cord-derived mesenchymal stem cells; ESCS, embryonic stem cells; WJ-MSCs, Wharton's jelly-derived mesenchymal stem cells; P-MMSCs, placenta-derived multipotent mesenchymal stem cells; AD-MSCs, adipose tissue-derived mesenchymal stem cells; DPSCs, dental pulp stem cells; EVs-CDCs, extracellular vesicles from cardiosphere-derived cells; DSC, decidual stroma cells; MSCS-Exo, mesenchymal stem cell derived exosomes; $h C T-M S C$, human cord tissue mesenchymal stromal cells; ULSC, umbilical cord lining stem cells; ARDS, acute respiratory distress syndrome; CB-MCS, cord blood-derived mesenchymal stem cell; S-MSCS, secretome-MSCs; COVI-MSC, allogeneic culture-expanded adipose-derived mesenchymal stem cells (MSCs); HB-adMSCs, Hope Biosciences allogeneic adipose-derived mesenchymal stem cells; LMSCs, Longeveron mesenchymal stem cells; $H B$-adMSCs, autologous adipose-derived mesenchymal stem cells; ACT-20-MSC, allogenic human umbilical derived mesenchymal stem cells; ACT-20-CM, allogenic human umbilical derived mesenchymal stem cells in conditioned media; CYP-001, Cymerus mesenchymal stem cells (MSCs). Remestemcel-L is a third-party of adult human mesenchymal stem cells; SBI-101 is a combination product: allogeneic human mesenchymal stromal cells (MSCs) and an FDA-approved plasmapheresis device; Descartes 30, mesenchymal stem cells or MSCs RNA-engineered to secrete a combination of DNases. Primepro, umbilical cord-derived stem cell

shown by different studies exploring similar products in terms of cell origin and minimal required characterization [156]. Therefore, there is an urgent need to identify the mechanisms of action in vivo and to further improve product characterization (e.g., through additional markers, potency assays) to increase the predictability of outcomes [157]. Moreover, to date, only small case series or case reports have been published, and although these are important for generating hypotheses, there is a need for larger randomized controlled clinical trials to generate further substantial evidence regarding the safety and effectiveness of such therapies.

Second, access and scalability should be further optimized. Due to their complexity and cost, cell-based therapies are unlikely to become first-line approaches for this disease, but might be beneficial to treat severe COVID-19 cases. With advances in MSC manufacturing technologies, the ability to produce an extensive quantity of cells for clinical use while maintaining their properties remains a challenge, but over time has become more feasible (i.e., application of 3D culture on microcarriers in bioreactors) [157]. With the need for continuous production qualification and comparability studies to mitigate the effects of donor/product heterogeneity and interbatch variability, novel strategies that utilize cell lines or iPSC-derived MSCs may contribute to increased feasibility and scalability [158]. However, product availability in real life requires extensive efforts not only in large-scale manufacturing but also in distribution and site qualification for adequate product handling until 
Table 2 Reports of clinical use of MSCs in COVID-19 patients

\begin{tabular}{|c|c|c|c|c|c|c|c|c|}
\hline $\begin{array}{l}\text { Study } \\
\text { phase/type }\end{array}$ & Country & $\begin{array}{l}\text { Sample } \\
\text { size }\end{array}$ & $\begin{array}{l}\text { Patient } \\
\text { characteristics }\end{array}$ & Cell product & $\begin{array}{l}\text { Dose and } \\
\text { administration } \\
\text { regimen }\end{array}$ & Main findings & Adverse events & References \\
\hline Pilot study & China & $\begin{array}{l}10 \\
\text { patients, } n \\
=7 \\
\text { included } \\
\text { in the cell } \\
\text { therapy } \\
\text { arm }\end{array}$ & $\begin{array}{l}\text { COVID-19 } \\
\text { pneumonia } \\
\text { confirmed by RT- } \\
\text { PCR, with no im- } \\
\text { provement under } \\
\text { standard treatment }\end{array}$ & $\begin{array}{l}\text { Allogeneic, } \\
\text { UC-MSC }\end{array}$ & $\begin{array}{l}\text { Single dose of } 1 \times \\
10^{6} \mathrm{MSCs} / \mathrm{kg} \text {, i.v. } \\
\text { infusion }\end{array}$ & $\begin{array}{l}\text { Improvement of } \\
\text { pulmonary } \\
\text { function and } \\
\text { symptoms, } \\
\text { increase of } \\
\text { peripheral } \\
\text { lymphocytes, } \\
\text { decrease in C- } \\
\text { reactive protein, } \\
\text { disappearance of } \\
\text { overactivated } \\
\text { cytokine-secreting } \\
\text { immune cells, de- } \\
\text { crease of TNF-a } \\
\text { levels and increase } \\
\text { of IL-10 levels }\end{array}$ & $\begin{array}{l}\text { No treatment- } \\
\text { related adverse } \\
\text { events }\end{array}$ & $\begin{array}{l}\text { Leng et al, } \\
2020 \text { [66] }\end{array}$ \\
\hline $\begin{array}{l}\text { Phase 1, } \\
\text { controlled, } \\
\text { open label }\end{array}$ & China & $\begin{array}{l}41 \\
\text { patients, } n \\
=12 \\
\text { included } \\
\text { in the cell } \\
\text { therapy } \\
\text { arm }\end{array}$ & $\begin{array}{l}\text { Severe COVID-19, } \\
\text { clinical symptoms } \\
\text { were not alleviated } \\
\text { under standard } \\
\text { treatment for } 7 \text { to } \\
10 \text { days }\end{array}$ & $\begin{array}{l}\text { Allogeneic, } \\
\text { UC-MSC }\end{array}$ & $\begin{array}{l}\text { Single dose of } 2 \times \\
10^{6} \mathrm{MSC} / \mathrm{kg} \text {, i.v. } \\
\text { infusion }\end{array}$ & $\begin{array}{l}\text { Relief of clinical } \\
\text { symptoms, } \\
\text { reduction of } \\
\text { inflammatory } \\
\text { factors, increase of } \\
\text { lymphocytes, } \\
\text { patients with } \\
\text { diabetes used less } \\
\text { exogenous insulin } \\
\text { after hUC-MSC in- } \\
\text { fusion than usual }\end{array}$ & $\begin{array}{l}\text { No treatment- } \\
\text { related adverse } \\
\text { events }\end{array}$ & $\begin{array}{l}\text { Shu et al, } \\
2020 \text { [139] }\end{array}$ \\
\hline $\begin{array}{l}\text { Primary safety } \\
\text { trial, open- } \\
\text { label cohort } \\
\text { study }\end{array}$ & USA & $\begin{array}{l}27 \\
\text { patients }\end{array}$ & $\begin{array}{l}\text { Severe or critical } \\
\mathrm{COVID}^{\prime} 19 \\
\mathrm{SpO}_{2}<94 \% \text { on } \\
\text { room air (RA), with } \\
\text { fever and dyspnea } \\
(n=2) ; \text { patients } \\
\text { with } \mathrm{SpO}_{2}<90 \% \\
\text { on } \mathrm{RA} \text { or patients } \\
\text { who required } \\
\text { supplemental } \\
\text { oxygen to maintain } \\
\mathrm{SpO}_{2}<94 \%(n= \\
21) \text {, and patients } \\
\text { with hypoxic } \\
\text { respiratory failure } \\
\text { on mechanical } \\
\text { ventilation }(n=4)\end{array}$ & $\begin{array}{l}\text { Allogeneic, } \\
\text { MSC-Exo }\end{array}$ & $\begin{array}{l}15 \mathrm{ml} \text { of ExoFlo } \\
\text { was added to } \\
100 \mathrm{~mL} \text { of normal } \\
\text { saline, i.v. infusion } \\
\text { Quantification } \\
\text { and } \\
\text { characterization of } \\
\text { exosomes were } \\
\text { not provided }\end{array}$ & $\begin{array}{l}\text { Reversal of } \\
\text { hypoxia, immune } \\
\text { reconstitution, } \\
\text { modulation of } \\
\text { cytokine storm }\end{array}$ & $\begin{array}{l}\text { No treatment- } \\
\text { related adverse } \\
\text { events }\end{array}$ & $\begin{array}{l}\text { Sengupta } \\
\text { et al, } 2020 \\
{[140]}\end{array}$ \\
\hline $\begin{array}{l}\text { Case series/ } \\
\text { Retrospective } \\
\text { study }\end{array}$ & China & $\begin{array}{l}25 \\
\text { patients }\end{array}$ & $\begin{array}{l}\text { Severe COVID-19 } \\
\text { confirmed by real- } \\
\text { time RT-PCR assay; } \\
\text { patients in respira- } \\
\text { tory distress, with } \\
\mathrm{RR} \geq 30 \text { beats/min, } \\
\text { oxygen saturation } \\
\text { level } \leq 93 \% \text { in rest- } \\
\text { ing state and arter- } \\
\text { ial partial pressure } \\
\text { of oxygen }\left(\mathrm{PaO}_{2}\right) / \\
\text { fraction of inspir- } \\
\text { ation } \mathrm{O} 2\left(\mathrm{FiO}_{2}\right) \leq \\
300 \mathrm{mmHg}\end{array}$ & $\begin{array}{l}\text { MSCs of non- } \\
\text { specified } \\
\text { origin }\end{array}$ & $\begin{array}{l}1 \times 10^{6} \mathrm{MSCs} / \mathrm{kg} \text {, } \\
\text { i.v. infusion, single } \\
\text { dose }(n=7) \text {, two } \\
\text { doses }(n=7) \text {, } \\
\text { three doses ( } n= \\
\text { 11) }\end{array}$ & $\begin{array}{l}\text { Effectiveness, } \\
\text { serum levels of } \\
\text { LAC, CTnT and CK- } \\
\text { MB were elevated } \\
\text { significantly after } \\
\text { MSCs therapy }\end{array}$ & $\begin{array}{l}\text { Three cases } \\
\text { experienced } \\
\text { treatment-related } \\
\text { side effects, spe- } \\
\text { cifically liver dys- } \\
\text { function, heart } \\
\text { failure and allergic } \\
\text { rash }\end{array}$ & $\begin{array}{l}\text { Chen et al, } \\
2020 \text { [141] }\end{array}$ \\
\hline Case report & China & 1 patient & $\begin{array}{l}\text { RT-PCR assay } \\
\text { confirmed that the } \\
\text { patient's specimen } \\
\text { tested positive for } \\
\text { COVID-19, severe } \\
\text { shortness of breath, }\end{array}$ & $\begin{array}{l}\text { Allogeneic, } \\
\text { UC-MSC }\end{array}$ & $\begin{array}{l}\text { Single dose of } 1 \times \\
10^{6} \mathrm{MSCs} / \mathrm{kg} \text {, i.v. } \\
\text { infusion }\end{array}$ & $\begin{array}{l}\text { Improvement of } \\
\text { pulmonary } \\
\text { function and } \\
\text { symptoms, } \\
\text { increase of } \\
\text { lymphocyte }\end{array}$ & $\begin{array}{l}\text { No treatment- } \\
\text { related adverse } \\
\text { events }\end{array}$ & $\begin{array}{l}\text { Zhang } \\
\text { et al, } 2020 \\
{[142]}\end{array}$ \\
\hline
\end{tabular}


Table 2 Reports of clinical use of MSCs in COVID-19 patients (Continued)

\begin{tabular}{|c|c|c|c|c|c|c|c|c|}
\hline $\begin{array}{l}\text { Study } \\
\text { phase/type }\end{array}$ & Country & $\begin{array}{l}\text { Sample } \\
\text { size }\end{array}$ & $\begin{array}{l}\text { Patient } \\
\text { characteristics }\end{array}$ & Cell product & $\begin{array}{l}\text { Dose and } \\
\text { administration } \\
\text { regimen }\end{array}$ & Main findings & Adverse events & References \\
\hline & & & $\begin{array}{l}\mathrm{SpO}_{2} \text { of } 87.9 \%, \\
\text { computerized tom- } \\
\text { ography evidences } \\
\text { pneumonia and } \\
\text { ground-glass opa- } \\
\text { city in bilateral } \\
\text { lungs }\end{array}$ & & & $\begin{array}{l}\text { subsets, decrease } \\
\text { of IL-6, TNF-a, and } \\
\text { C-reactive protein } \\
\text { levels, safety and } \\
\text { efficiency }\end{array}$ & & \\
\hline Pilot study & China & 2 patients & $\begin{array}{l}\text { Severe COVID-19; } \\
\text { patient } 1 \text { with in- } \\
\text { creased leukocyte } \\
\text { count and neutro- } \\
\text { phils, decreased } \\
\text { hemoglobin and } \\
\text { lymphocytes, X-ray } \\
\text { indicates large, } \\
\text { patchy, high-density } \\
\text { lesions in bilateral } \\
\text { lungs; patient } 2 \\
\text { with increased neu- } \\
\text { trophils and de- } \\
\text { creased leukocyte } \\
\text { counts and lympho- } \\
\text { cytes, chest X-ray } \\
\text { indication of patchy } \\
\text { high-density } \\
\text { shadows in the } \\
\text { lower lung fields } \\
\text { and left middle } \\
\text { lung }\end{array}$ & $\begin{array}{l}\text { Allogeneic, } \\
\text { menstrual } \\
\text { blood- } \\
\text { derived MSC }\end{array}$ & $\begin{array}{l}\text { Three infusions of } \\
1 \times 10^{6} \mathrm{MSCs} / \mathrm{kg} \\
\text { i.v. infusion }\end{array}$ & $\begin{array}{l}\text { MSC } \\
\text { transplantation } \\
\text { increases the } \\
\text { immune indicators } \\
\text { (including CD4 } \\
\text { and lymphocytes) } \\
\text { and decreases the } \\
\text { inflammation } \\
\text { indicators } \\
\text { (interleukin- } 6 \text { and } \\
\text { C-reactive protein), } \\
\text { improvement of } \\
\text { dyspnea and lung } \\
\text { function }\end{array}$ & $\begin{array}{l}\text { No treatment- } \\
\text { related adverse } \\
\text { events }\end{array}$ & $\begin{array}{l}\text { Tang et al, } \\
2020 \text { [143] }\end{array}$ \\
\hline $\begin{array}{l}\text { Proof of } \\
\text { concept }\end{array}$ & Spain & $\begin{array}{l}13 \\
\text { patients }\end{array}$ & $\begin{array}{l}\text { COVID-associated } \\
\text { pneumonia } \\
\text { requiring } \\
\text { mechanical } \\
\text { ventilation in the } \\
\text { ICU }\end{array}$ & $\begin{array}{l}\text { Allogeneic } \\
\text { AT-MSC }\end{array}$ & $\begin{array}{l}\text { Median number } \\
\text { of AT-MSCs per } \\
\text { dose was } 0.98 \\
\text { (IQR } 0.5) \times 10^{6} / \mathrm{kg} \\
\text { Single dose }(n= \\
\text { 2), two doses }(n= \\
\text { 10); three doses ( } n \\
=1) \text {, interval of } 3 \\
\text { days }\end{array}$ & $\begin{array}{l}9 \text { patients } \\
\text { improved clinically } \\
\text { and } 7 \text { were } \\
\text { extubated with a } \\
\text { median time from } \\
\text { the first MSC dose } \\
\text { to extubation of } 7 \\
\text { days. Radiological } \\
\text { improvement in } \\
\text { sequential X-rays } \\
\text { was confirmed in } \\
40 \% \text { of evaluable } \\
\text { patients. A de- } \\
\text { crease in inflam- } \\
\text { matory parameters } \\
\text { at day } 5 \text { after infu- } \\
\text { sion with a de- } \\
\text { crease in C- } \\
\text { reactive protein in } \\
8 \text { patients (88\%), } \\
\text { LDH in } 9 \text { (100\%), } \\
\text { and D-dimer and } \\
\text { ferritin in } 5 \text { of } 8 \\
\text { evaluable patients } \\
\text { (63\%), increase in } \\
\text { the levels of total } \\
\text { lymphocytes was } \\
\text { observed in re- } \\
\text { sponders patients } \\
\text { (B, CD4, CD8) }\end{array}$ & $\begin{array}{l}\text { No treatment- } \\
\text { related adverse } \\
\text { events }\end{array}$ & $\begin{array}{l}\text { Sánchez- } \\
\text { Guijo et al, } \\
2020 \text { [130] }\end{array}$ \\
\hline Case series & Brazil & $\begin{array}{l}10 \\
\text { patients, } n \\
=7 \text { in cell } \\
\text { therapy } \\
\text { arm }\end{array}$ & $\begin{array}{l}\text { COVID-associated } \\
\text { pneumonia, } \\
\text { presenting severe } \\
\text { acute respiratory } \\
\text { syndrome }\end{array}$ & $\begin{array}{l}\text { MSCs of non- } \\
\text { specified } \\
\text { origin }\end{array}$ & $\begin{array}{l}\text { Single dose of } 1 \times \\
10^{6} \mathrm{MSCs} / \mathrm{kg} \text {, i.v. } \\
\text { infusion }\end{array}$ & $\begin{array}{l}\text { Improvement in } \\
\text { symptoms, } \\
\text { significant } \\
\text { reduction ofchest } \\
\text { infiltration, } \\
\text { reduction of pro- }\end{array}$ & $\begin{array}{l}\text { No treatment- } \\
\text { related adverse } \\
\text { events }\end{array}$ & $\begin{array}{l}\text { Mazzeo } \\
\text { and Santos, } \\
2020[144]\end{array}$ \\
\hline
\end{tabular}


Table 2 Reports of clinical use of MSCs in COVID-19 patients (Continued)

\begin{tabular}{|c|c|c|c|c|c|c|c|c|}
\hline $\begin{array}{l}\text { Study } \\
\text { phase/type }\end{array}$ & Country & $\begin{array}{l}\text { Sample } \\
\text { size }\end{array}$ & $\begin{array}{l}\text { Patient } \\
\text { characteristics }\end{array}$ & Cell product & $\begin{array}{l}\text { Dose and } \\
\text { administration } \\
\text { regimen }\end{array}$ & Main findings & Adverse events & References \\
\hline & & & & & & $\begin{array}{l}\text { inflammatory cyto- } \\
\text { kines (TNF-a), in- } \\
\text { crease of } \\
\text { peripheral } \\
\text { lymphocyte } \\
\text { counts (CD4+ T } \\
\text { cells and dendritic } \\
\text { cells), increase of } \\
\text { anti-inflammatory } \\
\text { gene expression } \\
\text { and trophic } \\
\text { factors }\end{array}$ & & \\
\hline Case report & China & 1 patient & $\begin{array}{l}\text { Severe COVID-19 } \\
\text { confirmed by RT- } \\
\mathrm{PCR}, \mathrm{SpO}_{2} 90 \%, \mathrm{P} / \mathrm{F} \\
243 \mathrm{mmHg} \text {, pul- } \\
\text { monary exudative } \\
\text { lesions in bilateral } \\
\text { lungs showed in X- } \\
\text { ray }\end{array}$ & $\begin{array}{l}\text { Convalescent } \\
\text { plasma + UC- } \\
\text { MSC }\end{array}$ & $\begin{array}{l}\text { Three infusions of } \\
1 \times 10^{6} \mathrm{MSCs} / \mathrm{kg} \text {, } \\
\text { i.v. infusion }\end{array}$ & $\begin{array}{l}\text { Restoration of } \\
\text { lung diffusion, } \\
\text { improvement of } \\
\text { pulmonary } \\
\text { function, increase } \\
\text { of oxygenation } \\
\text { index, } \mathrm{PaO}_{2} \text { and } \\
\text { absolute } \\
\text { lymphocyte count, } \\
\text { decline in } \\
\text { absolute } \\
\text { neutrophils count } \\
\text { and IL-6 }\end{array}$ & $\begin{array}{l}\text { No treatment- } \\
\text { related adverse } \\
\text { events }\end{array}$ & $\begin{array}{l}\text { Peng et al, } \\
2020 \text { [145] }\end{array}$ \\
\hline Pilot study & China & $\begin{array}{l}31 \\
\text { patients }\end{array}$ & $\begin{array}{l}\text { Severe }(n=23) \text { or } \\
\text { critical }(n=8) \\
\text { COVID-19 }\end{array}$ & $\begin{array}{l}\text { Allogeneic, } \\
\text { UC-MSC }\end{array}$ & $\begin{array}{l}\text { Single }(n=11) \text {, } \\
\text { two }(n=9) \text { or } \\
\text { three }(n=11) \\
\text { infusions of } 1 \times \\
10^{6} \text { MSCs } / \mathrm{kg} \mathrm{BW,} \\
\text { i.v. infusion }\end{array}$ & $\begin{array}{l}\text { Restoration of } \\
\text { oxygenation, } \\
\text { downregulation of } \\
\text { cytokine storm, } \\
\text { improvement of } \\
\text { lung function. } \\
\text { Laboratory } \\
\text { parameters } \\
\text { tended to } \\
\text { improve after UC- } \\
\text { MSC therapy com- } \\
\text { pared to the sta- } \\
\text { tus before UC- } \\
\text { MSC therapy, in- } \\
\text { cluding elevated } \\
\text { lymphocyte count, } \\
\text { decreased C- } \\
\text { reactive protein } \\
\text { level and procalci- } \\
\text { tonin level, de- } \\
\text { creased D-Dimer } \\
\text { levels }\end{array}$ & $\begin{array}{l}\text { No treatment- } \\
\text { related adverse } \\
\text { events }\end{array}$ & $\begin{array}{l}\text { Guo et al, } \\
2020 \text { [146] }\end{array}$ \\
\hline Case report & China & 1 patient & $\begin{array}{l}\text { Severe COVID-19, } \\
\mathrm{SpO}_{2} \text { of } 81 \% \text {, chest } \\
\text { tightness, blood } \\
\text { pressure of } 160 / 91 \\
\text { mmHg and X-ray } \\
\text { showing ground- } \\
\text { glass opacity in } \\
\text { right lung }\end{array}$ & $\begin{array}{l}\text { Allogeneic, } \\
\text { UC-MSC }\end{array}$ & $\begin{array}{l}\text { Three cycles }(5 \times \\
10^{7} \text { cells each } \\
\text { time) with a 3-day } \\
\text { interval, i.v. } \\
\text { infusion }\end{array}$ & $\begin{array}{l}\text { Improvement of } \\
\text { clinical indexes } \\
\text { and symptoms, } \\
\text { reversal of } \\
\text { lymphopenia } \\
\text { (increase in counts } \\
\text { of CD3+ T cell, } \\
\text { CD4+ T cell and } \\
\text { CD8+ T cell) }\end{array}$ & $\begin{array}{l}\text { No treatment- } \\
\text { related adverse } \\
\text { events }\end{array}$ & $\begin{array}{l}\text { Liang et al, } \\
2020 \text { [147] }\end{array}$ \\
\hline $\begin{array}{l}\text { Phase 1, } \\
\text { controlled, } \\
\text { open label }\end{array}$ & China & $\begin{array}{l}18 \\
\text { patients; } n \\
=9 \\
\text { included } \\
\text { in the cell } \\
\text { therapy } \\
\text { arm }\end{array}$ & $\begin{array}{l}\text { Moderate and } \\
\text { severe COVID-19 } \\
\text { confirmed by RT- } \\
\text { PCR; pneumonia } \\
\text { was evidenced } \\
\text { using chest radiog- } \\
\text { raphy or CT; moder- } \\
\text { ate cases were }\end{array}$ & $\begin{array}{l}\text { Allogeneic, } \\
\text { UC-MSC }\end{array}$ & $\begin{array}{l}\text { Three cycles of i.v. } \\
\text { infusion of } \\
\text { allogeneic UC- } \\
\text { MSCs ( } 3 \times 10^{7} \\
\text { cells each infu- } \\
\text { sion) on days } 0,3 \text {, } \\
\text { and } 6\end{array}$ & $\begin{array}{l}\text { Decrease of serum } \\
\text { IL-6 biomarker of } \\
\text { disease progres- } \\
\text { sion, improvement } \\
\text { of percentage of } \\
\text { inspired oxygen } \\
\text { ratio, faster ab- } \\
\text { sorption of lung }\end{array}$ & $\begin{array}{l}\text { Two patients } \\
\text { developed } \\
\text { transient facial } \\
\text { flushing and fever, } \\
\text { and one patient } \\
\text { developed } \\
\text { transient hypoxia } \\
\text { at } 12 \mathrm{~h} \text { post UC- }\end{array}$ & $\begin{array}{l}\text { Meng et al, } \\
2020 \text { [148] }\end{array}$ \\
\hline
\end{tabular}


Table 2 Reports of clinical use of MSCs in COVID-19 patients (Continued)

\begin{tabular}{|c|c|c|c|c|c|c|c|c|}
\hline $\begin{array}{l}\text { Study } \\
\text { phase/type }\end{array}$ & Country & $\begin{array}{l}\text { Sample } \\
\text { size }\end{array}$ & $\begin{array}{l}\text { Patient } \\
\text { characteristics }\end{array}$ & Cell product & $\begin{array}{l}\text { Dose and } \\
\text { administration } \\
\text { regimen }\end{array}$ & Main findings & Adverse events & References \\
\hline & & & $\begin{array}{l}\text { defined as fever, re- } \\
\text { spiratory symptoms } \\
\text { and confirmed } \\
\text { pneumonia; severe } \\
\text { cases included } \\
\text { symptoms of short- } \\
\text { ness of breath or } \\
\text { dyspnea after } \\
\text { activity }\end{array}$ & & & lesions & MSCs infusion & \\
\hline Case report & China & 1 patient & $\begin{array}{l}\text { COVID-19 } \\
\text { confirmed by RT- } \\
\text { PCR, acute respira- } \\
\text { tory distress, } \mathrm{SpO}_{2} \\
90 \% \text {, computerized } \\
\text { tomography } \\
\text { showed ground- } \\
\text { glass opacity in } \\
\text { both lungs, multiple } \\
\text { organ injury (hep- } \\
\text { atic respiratory sys- } \\
\text { tem), } \\
\text { immunosuppression }\end{array}$ & $\begin{array}{l}\text { Allogeneic, } \\
\text { UC-MSC }\end{array}$ & $\begin{array}{l}\text { Single infusion of } \\
1 \times 10^{6} \mathrm{MSCs} / \mathrm{kg} \\
\text { BW, i.v. infusion }\end{array}$ & $\begin{array}{l}\text { Patient's } \mathrm{SpO}_{2} \\
\text { returned to the } \\
\text { normal level } 48 \mathrm{~h} \\
\text { after MSC infusion, } \\
\text { non-invasive venti- } \\
\text { lator was success- } \\
\text { fully removed } \\
\text { after } 6 \text { days. BUN, } \\
\mathrm{PCT}, \mathrm{CRP}, \mathrm{AST} \text {, and } \\
\mathrm{ALT} \text { levels de- } \\
\text { creased, leuco- } \\
\text { cytes gradually } \\
\text { recovered after } 13 \\
\text { days }\end{array}$ & $\begin{array}{l}\text { No treatment- } \\
\text { related adverse } \\
\text { events }\end{array}$ & $\begin{array}{l}\text { Zhu et al, } \\
2020 \text { [149] }\end{array}$ \\
\hline $\begin{array}{l}\text { Phase 2, } \\
\text { randomized, } \\
\text { double-blind, } \\
\text { placebo- } \\
\text { controlled }\end{array}$ & China & $\begin{array}{l}101 \\
\text { patients; } n \\
=65 \\
\text { included } \\
\text { in the cell } \\
\text { therapy } \\
\text { arm; } n= \\
45 \text { control, } \\
n=1 \\
\text { excluded }\end{array}$ & $\begin{array}{l}\text { Severe COVID-19 } \\
\text { confirmed by RT- } \\
\text { PCR; pneumonia } \\
\text { was evidenced } \\
\text { using chest com- } \\
\text { puted radiography } \\
\text { (CT) imaging. Dys- } \\
\text { pnea (respiratory } \\
\text { rate } \geq 30 \text { times/ } \\
\text { min), oxygen satur- } \\
\text { ation of } 93 \% \text { or } \\
\text { lower on room air; } \\
\text { arterial oxygen par- } \\
\text { tial pressure (PaO }) / \\
\text { fraction of inspired } \\
\text { oxygen } \leq 300 \\
\text { mmHg; pulmonary } \\
\text { imaging showing } \\
\text { that the foci pro- } \\
\text { gressed by }>50 \% \\
\text { in } 24-48 \mathrm{~h}\end{array}$ & $\begin{array}{l}\text { Allogeneic, } \\
\text { UC-MSCs }\end{array}$ & $\begin{array}{l}\text { Three cycles of i.v. } \\
\text { infusions of UC- } \\
\text { MSCs }(4 \times 107 \\
\text { cells) each on } \\
\text { days } 0,3 \text {, and } 6\end{array}$ & $\begin{array}{l}\text { UC-MSC } \\
\text { administration } \\
\text { was safe and } \\
\text { accelerated } \\
\text { resolution of lung } \\
\text { solid component } \\
\text { lesions and } \\
\text { improvement in } \\
\text { the integrated } \\
\text { reserve capability } \\
\text { after UC-MSC } \\
\text { administration }\end{array}$ & $\begin{array}{l}\text { Adverse events } \\
\text { reported during } \\
\text { the study was } \\
\text { similar in the MSC } \\
\text { group and the } \\
\text { placebo group. All } \\
\text { adverse events } \\
\text { during the } \\
\text { observation } \\
\text { period were } \\
\text { judged by the site } \\
\text { investigators and } \\
\text { found to be } \\
\text { unrelated to UC- } \\
\text { MSC intervention. } \\
\text { No deaths were } \\
\text { observed in this } \\
\text { trial. }\end{array}$ & $\begin{array}{l}\text { Shi et al, } \\
2021 \text { [150] }\end{array}$ \\
\hline Phase 1 & Iran & $\begin{array}{l}11 \\
\text { patients }\end{array}$ & $\begin{array}{l}\text { COVID-19 } \\
\text { confirmed by RT- } \\
\text { PCR or chest X-ray; } \\
\mathrm{SpO}_{2} / \mathrm{FiO}_{2} \leq 315 \text {, } \\
\text { SOFA score be- } \\
\text { tween } 2 \text { and } 13 \\
\text { point, required } \\
\text { mechanical ventila- } \\
\text { tion and/or supple- } \\
\text { mental oxygen }\end{array}$ & $\begin{array}{l}\text { (UC-MSC) or } \\
\text { (PL-MSC) }\end{array}$ & $\begin{array}{l}\text { Three i.v. infusions } \\
(200 \times 106 \text { cells) } \\
\text { every other day } \\
\text { for a total of } 600 \\
\times 106 \text { human } \\
\text { umbilical cord } \\
\text { MSCs (UC-MSCs; } 6 \\
\text { cases) or placental } \\
\text { MSCs (PL-MSCs; } 5 \\
\text { cases) }\end{array}$ & $\begin{array}{l}\text { MSCs from a } \\
\text { prenatal source is } \\
\text { relatively safe, } \\
\text { tolerable, and } \\
\text { could rapidly } \\
\text { improve } \\
\text { respiratory } \\
\text { symptoms and } \\
\text { reduce } \\
\text { inflammatory } \\
\text { conditions in } \\
\text { some critically ill } \\
\text { coVID-19 patients }\end{array}$ & $\begin{array}{l}\text { Two patients } \\
\text { developed } \\
\text { shivering that } \\
\text { occurred during } \\
\text { the initial PL-MSC } \\
\text { infusion, which } \\
\text { was relieved by } \\
\text { supportive treat- } \\
\text { ment in less than } \\
1 \mathrm{~h} \text {. This shivering } \\
\text { did not develop } \\
\text { again during the } \\
\text { second and third } \\
\text { infusions. }\end{array}$ & $\begin{array}{l}\text { Hashemian } \\
\text { et al. } 2021 \\
\text { [151] }\end{array}$ \\
\hline Pilot study & China & $\begin{array}{l}17 \\
\text { patients, } n \\
=9 \\
\text { severe } \\
\text { and } n=7 \\
\text { critically }\end{array}$ & $\begin{array}{l}\text { Severe COVID- } 19 \\
\text { with respiratory dis- } \\
\text { tress, RR } \geq 30 \\
\text { min }^{-1}, \text { oxygen sat- } \\
\text { uration } \leq 93 \% \text { at } \\
\text { rest state, }\end{array}$ & $\begin{array}{l}\text { Allogeneic } \\
\text { UC-MSCs }\end{array}$ & $\begin{array}{l}\text { Four i.v. infusions } \\
\text { of }(1 \times 108 \text { cells }) \\
\text { with } 1 \text {-day inter- } \\
\text { vals in between }\end{array}$ & $\begin{array}{l}\text { UC-MSCs was safe } \\
\text { in severe and } \\
\text { critically severe } \\
\text { COVID-19 pneu- } \\
\text { monia and that } \\
\text { administration of }\end{array}$ & $\begin{array}{l}\text { There were two } \\
\text { severe adverse } \\
\text { events (SAE) } \\
\text { during the trial. } \\
\text { The two SAEs } \\
\text { were considered }\end{array}$ & $\begin{array}{l}\text { Feng et al. } \\
2020 \text { [152] }\end{array}$ \\
\hline
\end{tabular}


Table 2 Reports of clinical use of MSCs in COVID-19 patients (Continued)

\begin{tabular}{|c|c|c|c|c|c|c|c|c|}
\hline $\begin{array}{l}\text { Study } \\
\text { phase/type }\end{array}$ & Country & $\begin{array}{l}\text { Sample } \\
\text { size }\end{array}$ & $\begin{array}{l}\text { Patient } \\
\text { characteristics }\end{array}$ & Cell product & $\begin{array}{l}\text { Dose and } \\
\text { administration } \\
\text { regimen }\end{array}$ & Main findings & Adverse events & References \\
\hline & & $\begin{array}{l}\text { severe, } n \\
=1 \\
\text { excluded }\end{array}$ & $\begin{array}{l}\text { oxygenation index } \\
\leq 300 \mathrm{mmHg}, 1 \\
\mathrm{mmHg}=0.133 \mathrm{kPa} \\
\text { or critically severe } \\
\text { with respiratory fail- } \\
\text { ure needs mechan- } \\
\text { ical ventilation } \\
\text { Shock, combined } \\
\text { with other organ } \\
\text { failure, patients } \\
\text { need ICU } \\
\text { monitoring and } \\
\text { treatment }\end{array}$ & & & $\begin{array}{l}\text { UC-MSCs is associ- } \\
\text { ated with clinical } \\
\text { benefit and } \\
\text { changes in inflam- } \\
\text { matory and im- } \\
\text { mune populations }\end{array}$ & $\begin{array}{l}\text { to have no } \\
\text { relationship with } \\
\text { UC-MSCs } \\
\text { transplantation. }\end{array}$ & \\
\hline Pilot study & China & $\begin{array}{l}7 \text { patients, } \\
n=2 \\
\text { severe } \\
\text { cases, } n= \\
5 \text { mild } \\
\text { cases }\end{array}$ & $\begin{array}{l}\text { COVID-19 } \\
\text { confirmed by RT- } \\
\text { PCR }\end{array}$ & $\begin{array}{l}\text { MSC-derived } \\
\text { exosomes }\end{array}$ & $\begin{array}{l}\text { Nebulization of } \\
\text { MSC-derived exo- } \\
\text { somes. The con- } \\
\text { centration of } \\
\text { exosomes for } \\
\text { nebulization for } \\
\text { each patient } \\
\text { ranged from } \\
7.66 e+0.8 \text { to } \\
7.00 \text { e+0.7 parti- } \\
\text { cles/ml based on } \\
\text { NanoSight. }\end{array}$ & $\begin{array}{l}\text { The nebulization } \\
\text { of MSC-derived } \\
\text { exosomes is safe } \\
\text { and beneficial for } \\
\text { the absorption of } \\
\text { pulmonary lesions } \\
\text { in mild cases of } \\
\text { COVID-19 pneu- } \\
\text { monia and in re- } \\
\text { ducing cellular } \\
\text { residue in severe } \\
\text { cases. }\end{array}$ & $\begin{array}{l}\text { No adverse events } \\
\text { were reported }\end{array}$ & $\begin{array}{l}\text { Chu et al. } \\
2021 \text { [153] }\end{array}$ \\
\hline $\begin{array}{l}\text { Phase I } \\
\text { double-blind, } \\
\text { randomized, } \\
\text { controlled }\end{array}$ & USA & $\begin{array}{l}28 \\
\text { patients, } n \\
=12 \\
\text { included } \\
\text { in the cell } \\
\text { therapy } \\
\text { arm; } n= \\
12 \text { control, } \\
n=4 \\
\text { excluded }\end{array}$ & $\begin{array}{l}\text { COVID-19 } \\
\text { confirmed by RT- } \\
\text { PCR, peripheral ca- } \\
\text { pillary oxygen satur- } \\
\text { ation }\left(\mathrm{SpO}_{2}\right) \leq 94 \% \\
\text { at room air, or re- } \\
\text { quiring supplemen- } \\
\text { tal oxygen at } \\
\text { screening, } \mathrm{PaO} / \\
\mathrm{FiO}_{2} \text { ratio }<300 \\
\mathrm{mmHg}_{1} \text { Bilateral in- } \\
\text { filtrates on frontal } \\
\text { chest radiograph or } \\
\text { bilateral ground- } \\
\text { glass opacities on a } \\
\text { chest } \mathrm{CT} \text { scan }\end{array}$ & $\begin{array}{l}\text { Allogeneic } \\
\text { UC-MSC }\end{array}$ & $\begin{array}{l}\text { Two i.v. infusions } \\
\text { of }(100 \pm 20 \times \\
\text { 106) }\end{array}$ & $\begin{array}{l}\text { UC-MSC treatment } \\
\text { was safe, reduced } \\
\text { mortality and } \\
\text { recovery time. } \\
\text { Inflammatory } \\
\text { cytokines were } \\
\text { significantly } \\
\text { decreased in UC- } \\
\text { MSC-treated sub- } \\
\text { jects at day } 6 .\end{array}$ & $\begin{array}{l}\text { In the UC-MSC } \\
\text { treatment group, } \\
\text { the only reported } \\
\text { adverse event oc- } \\
\text { curred in a subject } \\
\text { with bradycardia } \\
\text { required transient } \\
\text { vasopressor } \\
\text { treatment. }\end{array}$ & $\begin{array}{l}\text { Lanzoni } \\
\text { et al., } 2021 \\
{[154]}\end{array}$ \\
\hline
\end{tabular}

MSCs, mesenchymal stem/stromal cells; UC-MSCs, umbilical cord-derived mesenchymal stem cells; AT-MSCs, adipose tissue-derived mesenchymal stem cells; MSCsExo, mesenchymal stem/stromal cell exosomes; $A R D S$, acute respiratory distress syndrome; $B W$, body weight; $P L-M S C$, placenta-derived mesenchymal stem cells

infusion. A complete logistic chain has been under development for the past few years since cell and gene therapy products have begun to reach the market [159].

Third, there is a need to not only determine safety and efficacy but also to investigate the ideal therapeutic window for cell-based therapies for severe COVID-19. The mechanisms of action of MSCs and previous preclinical and clinical experience suggest that early administration (i.e., during the first days of mechanical ventilation) might be beneficial in controlling inflammation, mitigating damage, and preventing later complications, such as lung fibrosis. This premise has been followed by most ongoing clinical trials (Table 1). It is important, however, that further studies provide data to support clinical indications, identify biomarkers to predict response, and evaluate cases of more advanced disease. Finally, although studies so far are scarce, there is a great opportunity to utilize MSC-derived exosomes as cell-free products instead of transferring living cells, which holds the potential to reduce risks and increase the predictability of outcomes.

\section{Conclusions}

The mechanistic rationale, preliminary data, and previous results of MSC-based therapies for the treatment of ARDS and other lung diseases make them a promising therapy for severe and critical cases of COVID-19. The mechanisms of action of MSCs, which combine antiviral, immunomodulatory, and antifibrotic actions, situate these products in a position to complement the current arsenal against COVID-19 and reduce current unmet medical needs. However, large randomized controlled 
clinical trials are still needed to properly evaluate the safety and efficacy of each specific cell product.

The success of cell-based therapies during a global health emergency such as COVID-19 might help accelerate the development of the whole field of cell and gene therapy by increasing knowledge diffusion among clinicians and solving logistics and manufacturing challenges.

\section{Abbreviations}

SARS: Severe acute respiratory syndrome; TMPRSS2: Transmembrane protease, serine 2; IL-2R: Interleukin-2 receptor; HLA: Human leukocyte antigen; SDF-1: Stromal cell-derived factor 1; CK-MB: Creatine phosphokinase-MB

\section{Acknowledgements}

The authors thank Dr. Kyan James Allahdadi, Filippe Vasconcellos, BA, and Lorna O'Brien (authorserv) for their assistance in editing the manuscript.

\section{Authors' contributions}

KNS, ALNG, PRMR, and BSFS wrote the manuscript. KNS, ALNG, and BSFS designed the review. BRRC, ACIC, FML, LSAF, CKVN, and MLP revised the manuscript. All authors contributed to the article and approved the submitted version.

\section{Funding}

This study was supported by Serrapilheira Institute, D'Or Institute for Research and Education (IDOR), Oswaldo Cruz Foundation (FIOCRUZ), the Brazilian Council for Scientific and Technological Development (CNPq), the Rio de Janeiro State Research Foundation (FAPERJ), the National Institute of Science and Technology for Regenerative Medicine (INCT-REGENERA), and Funding Authority for Studies and Projects (FINEP).

\section{Availability of data and materials}

Non applicable. No original data was included in this review, being comprised exclusively of published data.

\section{Declarations}

Ethics approval and consent to participate

Not applicable.

\section{Consent for publication}

Not applicable.

\section{Competing interests}

The authors declare that they have no competing interests.

\begin{abstract}
Author details
${ }^{1}$ Goncalo Moniz Institute, Oswaldo Cruz Foundation (FIOCRUZ), Rua Waldemar Falcão, 121, Candeal, Salvador, Bahia 40296-710, Brazil. ${ }^{2}$ D'Or Institute for Research and Education (IDOR), Salvador, Brazil. ${ }^{3}$ Center for Biotechnology and Cell Therapy, São Rafael Hospital, Salvador, Brazil. ${ }^{4}$ Graduate Program in Medicine and Health, Faculty of Medicine, Federal University of Bahia, Salvador, Brazil. ${ }^{5}$ Laboratory of Pulmonary Investigation, Carlos Chagas Filho Institute of Biophysics, Federal University of Rio de Janeiro, Rio de Janeiro, Brazil. ${ }^{6}$ National Institute of Science and Technology for Regenerative Medicine, Rio de Janeiro, Rio de Janeiro, Brazil. ${ }^{7}$ COVID-19 Virus Network, Ministry of Science and Technology, and Innovation, Rio de Janeiro, Brazil.
\end{abstract}

Received: 1 February 2021 Accepted: 4 July 2021

Published online: 27 July 2021

\section{References}

1. Adedokun KA, Olarinmoye AO, Olarinmoye AO, Mustapha JO, Kamorudeen RT. A close look at the biology of SARS-CoV-2, and the potential influence of weather conditions and seasons on COVID-19 case spread. Infect Dis Poverty. 2020;9:77. https://doi.org/10.1186/s40249-020-00688-1.
2. Velavan TP, Meyer CG. The COVID-19 epidemic. Trop Med Int Health. 2020; 25(3):278-80. https://doi.org/10.1111/tmi.13383.

3. García LF. Immune response, inflammation, and the clinical spectrum of COVID-19. Front Immunol. 2020;11:1441. https://doi.org/10.3389/fimmu.2020. 01441.

4. Robba C, Battaglini D, Pelosi P, Rocco PRM. Multiple organ dysfunction in SARS-CoV-2: MODS-CoV-2. Expert Rev Respir Med. 2020;14:865-8. https://doi. org/10.1080/17476348.2020.1778470.

5. Robba C, Battaglini D, Ball L, Patroniti N, Loconte M, Brunetti I, et al. Distinct phenotypes require distinct respiratory management strategies in severe COVID-19. Respir Physiol Neurobiol. 2020;279:103455. https://doi.org/10.101 6/j.resp.2020.103455.

6. Liu W, Tao ZW, Wang L, Yuan ML, Liu K, Zhou L, et al. Analysis of factors associated with disease outcomes in hospitalized patients with 2019 novel coronavirus disease. Chin Med J (Engl). 2020;133:1032-8. https://doi.org/10.1 097/CM9.0000000000000775

7. RECOVERY Collaborative Group, Horby P, Lim WS, Emberson JR, Mafham M, Bell JL, et al. Dexamethasone in hospitalized patients with Covid-19 preliminary report. N Engl J Med. 2020. https://doi.org/10.1056/NEJMoa2 021436

8. Beigel JH, Tomashek KM, Dodd LE, Mehta AK, Zingman BS, Kalil AC, et al. Remdesivir for the treatment of Covid-19 - preliminary report. N Engl J Med. 2020;383(19):1813-26. https://doi.org/10.1056/nejmoa2007764.

9. Magro G. SARS-CoV-2 and COVID-19: Is interleukin-6 (IL-6) the 'culprit lesion' of ARDS onset? What is there besides Tocilizumab? SGP130Fc. Cytokine X. 2020 Jun;2(2):100029. https://doi.org/10.1016/j.cytox.2020.100029.

10. Genovese MC, Fleischmann RM, Fiore $S$, et al. Sarilumab, a subcutaneouslyadministered, fully-human monoclonal antibody inhibitor of the IL-6 receptor: relationship between EULAR responses and change from baseline of selected clinical parameters. Ann Rheum Dis. 2013;72(Suppl 3):620.

11. Xu Z, Shi L, Wang Y, Zhang J, Huang L, Zhang C, et al. Pathological findings of COVID-19 associated with acute respiratory distress syndrome. Lancet Respir Med. 2020;8(4):420-2. https://doi.org/10.1016/S2213-2600(20)30076-X.

12. Stone $\mathrm{JH}$, Frigault MJ, Serling-Boyd NJ, et al. Efficacy of tocilizumab in patients hospitalized with Covid-19. N Engl J Med. 2020;383:2333-44. https://doi.org/10.1056/NEJMoa2028836.

13. Soin AS, Kumar K, Choudhary NS, et al. Lancet Respir Med. 2021. https://doi. org/10.1016/S2213-2600(21)00081-3. Epub ahead of print. PMID: 33676589

14. Salvarani C, Dolci G, Massari M, Merlo DF, Cavuto S, Savoldi L, et al. RCTTCZ-COVID-19 Study Group. Effect of tocilizumab vs standard care on clinical worsening in patients hospitalized with COVID-19 pneumonia: a randomized clinical trial. JAMA Intern Med. 2021;181(1):24-31. https://doi. org/10.1001/jamainternmed.2020.6615 PMID: 33080005; PMCID: PMC7577199.

15. Hermine $\mathrm{O}$, Mariette $X$, TharauX $\mathrm{PL}$, Resche-Rigon M, Porcher $\mathrm{R}$, Ravaud $\mathrm{P}$, et al. JAMA Intern Med. 2021;181(1):32-40. https://doi.org/10.1001/jama internmed.2020.6820 PMID: 33080017; PMCID: PMC7577198.

16. Salama C, Han J, Yau L, Reiss WG, Kramer B, Neidhart JD, et al. Tocilizumab in patients hospitalized with Covid-19 pneumonia. N Engl J Med. 2021; 384(1):20-30. https://doi.org/10.1056/NEJMoa2030340 Epub 2020 Dec 17. PMID: 33332779; PMCID: PMC7781101.

17. Horby PW, Pessoa-Amorim G, Peto L, et al. Tocilizumab in patients admitted to hospital with COVID-19 (RECOVERY): preliminary results of a randomised, controlled, open-label, platform trial. medRxiv. Published online February 11 , 20212021.02 .11 .21249258

18. Veiga VC, Prats JAGG, Farias DLC, Rosa RG et al. Effect of tocilizumab on clinical outcomes at 15 days in patients with severe or critical coronavirus disease 2019: randomised controlled trial. BMJ. 2021;372. https://doi.org/10.1136/bmj.n84

19. Rosas IO, Bräu N, Waters M, Go RC, Hunter BD, Bhagani S, et al. Tocilizumab in hospitalized patients with severe Covid-19 pneumonia. N Engl J Med. 2021. https://doi.org/10.1056/NEJMoa2028700. Epub ahead of print. PMID: 33631066.

20. Weinreich DM, Sivapalasingam S, Norton T, Ali S, Gao H, Bhore R, et al. REGN-COV2, a neutralizing antibody cocktail, in outpatients with Covid-19. N Engl J Med. 2021;384(3):238-51. https://doi.org/10.1056/NEJMoa2035002 Epub 2020 Dec 17. PMID: 33332778; PMCID: PMC7781102.

21. Lloyd EC, Gandhi TN, Petty LA. Monoclonal Antibodies for COVID-19. JAMA. 2021;325(10):1015. https://doi.org/10.1001/jama.2021.1225.

22. Casadevall A, Henderson J, Joyner M, Pirofski LA. SARS-Cov2 variants and convalescent plasma: reality, fallacies, and opportunities. J Clin Invest. 2021; 
23:148832. https://doi.org/10.1172/JCl148832 Epub ahead of print. PMID: 33621214.

23. Wibmer CK, Ayres F, Hermanus T, Madzivhandila M, Kgagudi P, Oosthuysen B, et al. SARS-CoV-2 501Y.V2 escapes neutralization by South African COVID19 donor plasma. bioRxiv [Preprint]. 2021:2021.01.18.427166. https://doi. org/10.1101/2021.01.18.427166 . Update in: Nat Med. 2021 Mar 2:: PMID: 33501446; PMCID: PMC7836116.

24. Moore JP, Offit PA. SARS-CoV-2 vaccines and the growing threat of viral variants. JAMA. 2021;325(9):821-2. https://doi.org/10.1001/jama.2021.1114.

25. Chen, R.E., Zhang, X., Case, J.B. et al. Resistance of SARS-CoV-2 variants to neutralization by monoclonal and serum-derived polyclonal antibodies. Nat Med. 2021. https://doi.org/10.1038/s41591-021-01294-w2.

26. Zhou D, Dejnirattisai W, Supasa P, Liu C, Mentzer AJ, Ginn HM, et al. Evidence of escape of SARS-CoV-2 variant B.1.351 from natural and vaccine induced sera, Cell. 2021. ISSN 0092-8674, https://doi.org/10.1016/j.cell.2021. 02.037.

27. George PM, Wells AU, Jenkins RG. Pulmonary fibrosis and COVID-19: the potential role for antifibrotic therapy. Lancet Respir Med. 2020;8(8):807-15. https://doi.org/10.1016/S2213-2600(20)30225-3

28. Khoury M, Cuenca J, Cruz FF, Figueroa FE, Rocco PRM, Weiss DJ, et al. Current status of cell-based therapies for respiratory virus infections: applicability to COVID-19. Eur Respir J. 2020;55(6):2000858. https://doi.org/1 0.1183/13993003.00858-2020.

29. Yan R, Zhang Y, Li Y, Xia L, Guo Y, Zhou Q. Structural basis for the recognition of SARS-CoV-2 by full-length human ACE2. Science. 2020;367: 1444-8. https://doi.org/10.1126/science.abb2762.

30. Samavati L, Uhal BD. ACE2, Much more than just a receptor for SARS-COV-2. Front Cell Infect Microbiol. 2020;10:317. https://doi.org/10.3389/fcimb.2020. 00317.

31. Zaim S, Chong JH, Sankaranarayanan V, Harky A. COVID-19 and multiorgan response. Curr Probl Cardiol. 2020;45:100618. https://doi.org/10.1016/j.cpca rdiol.2020.100618.

32. Gupta A, Madhavan MV, Sehgal K, Nair N, Mahajan S, Sehrawat TS, et al. Extrapulmonary manifestations of COVID-19. Nat Med. 2020;26:1017-32. https://doi.org/10.1038/s41591-020-0968-3.

33. Braga CL, Silva-Aguiar RP, Battaglini D, Peruchetti DB, Robba C, Pelosi P, et al. The renin-angiotensin-aldosterone system: role in pathogenesis and potential therapeutic target in COVID-19. Pharmacol Res Perspect. 2020;8: e00623. https://doi.org/10.1002/prp2.623.

34. Kuba K, Imai Y, Rao S, Gao H, Guo F, Guan B, et al. A crucial role of angiotensin converting enzyme 2 (ACE2) in SARS coronavirus-induced lung injury. Nat Med. 2005;11:875-9. https://doi.org/10.1038/nm1267.

35. Sawalha AH, Zhao M, Coit P, Lu Q. Epigenetic dysregulation of ACE2 and interferon-regulated genes might suggest increased COVID-19 susceptibility and severity in lupus patients. Clin Immunol. 2020;215:108410. https://doi. org/10.1016/j.clim.2020.108410.

36. Huang C, Wang Y, Li X, Ren L, Zhao J, Hu Y, et al. Clinical features of patients infected with 2019 novel coronavirus in Wuhan. China. Lancet. 2020;395:497-506. https://doi.org/10.1016/S0140-6736(20)30183-5.

37. Menter T, Haslbauer JD, Nienhold R, Savic S, Hopfer H, Deigendesch N, et al. Postmortem examination of COVID-19 patients reveals diffuse alveolar damage with severe capillary congestion and variegated findings in lungs and other organs suggesting vascular dysfunction. Histopathology. 2020;77: 198-209. https://doi.org/10.1111/his.14134.

38. Karki R, Sharma BR, Tuladhar S, Williams EP, Zalduondo L, Samir P, et al. Synergism of TNF-a and IFN- $\gamma$ triggers inflammatory cell death, tissue damage, and mortality in SARS-CoV-2 infection and cytokine shock syndromes. Cell. 2021;184(1):149-168.e17. https://doi.org/10.1016/j.cell.2020.11.025

39. Tang D, Comish P, Kang R. The hallmarks of COVID-19 disease. PLOS Pathogens. 2020;16(5):e1008536 https://doi.org/10.1371/journal.ppat. 1008536.

40. Naji A, Favier B, Deschaseaux F, Rouas-Freiss N, Eitoku M, Suganuma N. Mesenchymal stem/stromal cell function in modulating cell death. Stem Cell Res Ther. 2019;10(1):56. https://doi.org/10.1186/s13287-019-1158-4.

41. Ren Y, Shu T, Wu D, et al. The ORF3a protein of SARS-CoV-2 induces apoptosis in cells. Cell Mol Immunol. 2020;17:881-3. https://doi.org/10.1038/ s41423-020-0485-9.

42. Liu Y, Garron TM, Chang Q, Su Z, Zhou C, Gong EC, et al. Cell-type apoptosis in lung during SARS-CoV-2 infection. bioRxiv [Preprint]. 202:2020 12.23.424254. https://doi.org/10.1101/2020.12.23.424254. PMID: 33398280; PMCID: PMC7781315.
43. Yap JKY, Moriyama M, Iwasaki A. Inflammasomes and pyroptosis as therapeutic targets for COVID-19. J Immunol. 2020;205(2):307-12. https://doi. org/10.4049/jimmunol.2000513. Epub 2020 Jun 3. PMID: 32493814; PMCID: PMC7343621.

44. Bergsbaken T, Fink SL, Cookson BT. Pyroptosis: host cell death and inflammation. Nat Rev Microbiol. 2009;7(2):99-109. https://doi.org/10.1038/ nrmicro2070.

45. Nakanishi K, Yoshimoto T, Tsutsui H, Okamura H. Interleukin-18 regulates both Th1 and Th2 responses. Annu Rev Immunol. 2001;19(1):423-74.

46. Hadjadj J, Yatim N, Barnabei L, Corneau A, Boussier J, Smith N, et al. Impaired type I interferon activity and inflammatory responses in severe COVID-19 patients. Science. 2020;369(6504):718-24. https://doi.org/10.1126/ science.abc6027 Epub 2020 Jul 13. PMID: 32661059; PMCID: PMC7402632.

47. Blanco-Melo D, Nilsson-Payant BE, Liu W-C, et al. Imbalanced host response to SARS-CoV-2 drives development of COVID-19. Cell. 2020:181(5):10361045.e9.

48. Ragab D, Salah Eldin H, Taeimah M, Khattab R, Salem R. The COVID-19 cytokine storm; what we know so far. Front Immunol. 2020;11:1446. https:// doi.org/10.3389/fimmu.2020.01446 PMID: 32612617; PMCID: PMC7308649.

49. Mulchandani R, Lyngdoh T, Kakkar AK. Deciphering the COVID-19 cytokine storm: Systematic review and meta-analysis. Eur J Clin Invest. 2020;51: e13429. https://doi.org/10.1111/eci.13429.

50. Shrotri M, van Schalkwyk MCl, Post N, Eddy D, Huntley C, et al. T cell response to SARS-CoV-2 infection in humans: A systematic review. PLOS ONE. 2021;16(1):e0245532. https://doi.org/10.1371/journal.pone.0245532.

51. Jose RJ, Manuel A. COVID-19 cytokine storm: the interplay between inflammation and coagulation. Lancet Respir Med. 2020;8(6):e46-7. https:// doi.org/10.1016/S2213-2600(20)30216-2.

52. Dominici M, Le Blanc K, Mueller I, Slaper-Cortenbach I, Marini FC, Krause DS, et al. Minimal criteria for defining multipotent mesenchymal stromal cells. The International Society for Cellular Therapy position statement. Cytotherapy. 2006;8(4):315-7. https://doi.org/10.1080/14653240600855875.

53. Caplan Al. Mesenchymal stem cells: time to change the name! Stem Cells Transl Med. 2017;6:1445-51. https://doi.org/10.1002/sctm.17-0051.

54. Krasnodembskaya A, Song Y, Fang X, Gupta N, Serikov V, et al. Antibacterial effect of human mesenchymal stem cells is mediated in part from secretion of the antimicrobial peptide LL-37. Stem Cells. 2010;28:2229-38.

55. Rameshwar P. Microenvironment at tissue injury, a key focus for efficient stem cell therapy: a discussion of mesenchymal stem cells. World J Stem Cells. 2009;1:3. https://doi.org/10.4252/wjsc.v1.i1.3.

56. Lo Furno D, Mannino G, Giuffrida R. Functional role of mesenchymal stem cells in the treatment of chronic neurodegenerative diseases. J Cell Physiol. 2018;233(5):3982-99. https://doi.org/10.1002/jcp.26192.

57. Kim S, Yoon YM, Han YS, Lee JH, Hur J, Lee SH. Administration of Cripto in GRP78 overexpressed human MSCs enhances stem cell viability and angiogenesis during human MSC transplantation therapy. Cell Prolif. 2018; 51:e12463. https://doi.org/10.1111/cpr.12463.

58. Hoogduijn MJ, Lombardo E. Mesenchymal stromal cells anno 2019: dawn of the therapeutic era? Concise review. Stem Cells Transl Med. 2019;8:1126-34. https://doi.org/10.1002/sctm.19-0073.

59. Friedenstein AJ, Chailakhjan RK, Lalykina KS. The development of fibroblast colonies in monolayer cultures of guinea-pig bone marrow and spleen cells. Cell Prolif. 1970;3:393-403. https://doi.org/10.1111/j.1365-2184.1970.tb00347.x.

60. Guimarães-Camboa N, Cattaneo P, Sun Y, Moore-Morris T, Gu Y, Dalton ND, et al. Pericytes of multiple organs do not behave as mesenchymal stem cells in vivo. Cell Stem Cell. 2017;20:345-59.e5. https://doi.org/10.1016/j. stem.2016.12.006.

61. Hass R, Kasper C, Böhm S, Jacobs R. Different populations and sources of human mesenchymal stem cells (MSC): a comparison of adult and neonatal tissue-derived MSC. Cell Commun Signal. 2011;9:12. https://doi.org/10.11 83/1478-811X-9-12.

62. Laffey JG, Matthay MA. Cell-based therapy for acute respiratory distress syndrome: biology and potential therapeutic value. Am J Respir Crit Care Med. 2017;196:266-73. https://doi.org/10.1164/rccm.201701-0107CP.

63. Lopes-Pacheco M, Robba C, Rocco PRM, Pelosi P. Current understanding of the therapeutic benefits of mesenchymal stem cells in acute respiratory distress syndrome. Cell Biol Toxicol. 2020;36:83-102. https://doi.org/10.1007/ s10565-019-09493-5.

64. Spees JL, Lee RH, Gregory CA. Mechanisms of mesenchymal stem/stromal cell function. Stem Cell Res Ther. 2016;7:125. https://doi.org/10.1183/s13287016-0363-7. 
65. Cruz FF, Rocco PRM. Stem-cell extracellular vesicles and lung repair. Stem Cell Investig. 2017:4:78. https://doi.org/10.21037/sci.2017.09.02

66. Leng Z, Zhu R, Hou W, Feng Y, Yang Y, Han Q, et al. Transplantation of ACE2- mesenchymal stem cells improves the outcome of patients with COVID-19 pneumonia. Aging Dis. 2020;11:216. https://doi.org/10.14336/AD.2 020.0228 .

67. Liu Y, Wang L, Kikuiri T, Akiyama K, Chen C, Xu X, et al. Mesenchymal stem cell-based tissue regeneration is governed by recipient $\mathrm{T}$ lymphocytes via IFN- $\gamma$ and TNF-a. Nat Med. 2011;17:1594-601. https://doi.org/10.1038/nm.2 542.

68. Qu W, Wang Z, Hare JM, Bu G, Mallea JM, Pascual JM, et al. Cell-based therapy to reduce mortality from COVID-19: systematic review and metaanalysis of human studies on acute respiratory distress syndrome. Stem Cells Transl Med. 2020;9(9):1007-22. https://doi.org/10.1002/sctm.20-0146.

69. Leibacher J, Henschler R. Biodistribution, migration and homing of systemically applied mesenchymal stem/stromal cells - an update. Stem Cell Res Ther. 2016;7(1):7. https://doi.org/10.1183/s13287-015-0271-2

70. Eggenhofer E, Benseler V, Kroemer A, Popp FC, Geissler EK, Schlitt HJ, et al. Mesenchymal stem cells are short-lived and do not migrate beyond the lungs after intravenous infusion. Front Immunol. 2012;3:297. https://doi. org/10.3389/fimmu.2012.00297.

71. Chapel A, Bertho JM, Bensidhoum M, Fouillard L, Young RG, Frick J, et al. Mesenchymal stem cells home to injured tissues when co-infused with hematopoietic cells to treat a radiation-induced multi-organ failure syndrome. J Gene Med. 2003;5:1028-38. https://doi.org/10.1002/jgm.452.

72. Assis ACM, Carvalho JL, Jacoby BA, Ferreira RLB, Castanheira P, Diniz SOF, et al. Time-dependent migration of systemically delivered bone marrow mesenchymal stem cells to the infarcted heart. Cell Transplant. 2010;19:21930. https://doi.org/10.3727/096368879X479677

73. Jackson JS, Golding JP, Chapon C, Jones WA, Bhakoo KK. Homing of stem cells to sites of inflammatory brain injury after intracerebral and intravenous administration: a longitudinal imaging study. Stem Cell Res Ther. 2010;1:17. https://doi.org/10.1186/scrt17.

74. Jin SZ, Liu BR, Xu J, Gao FL, Hu ZJ, Wang XH, et al. Ex vivo-expanded bone marrow stem cells home to the liver and ameliorate functional recovery in a mouse model of acute hepatic injury. Hepatobiliary Pancreat Dis Int. 2012; 11:66-73. https://doi.org/10.1016/S1499-3872(11)60127-6.

75. Gholamrezanezhad A, Mirpour S, Bagheri M, Mohamadnejad M, Alimoghaddam K, Abdolahzadeh $\mathrm{L}$, et al. In vivo tracking of 111 In-oxine labeled mesenchymal stem cells following infusion in patients with advanced cirrhosis. Nucl Med Biol. 2011;38(7):961-7. https://doi.org/10.1016/ j.nucmedbio.2011.03.008.

76. Crop MJ, Baan CC, Korevaar SS, IJzermans JNM, Pescatori M, Stubbs AP, et al. Inflammatory conditions affect gene expression and function of human adipose tissue-derived mesenchymal stem cells. Clin Exp Immunol. 2010; 162(3):474-86. https://doi.org/10.1111/j.1365-2249.2010.04256.x.

77. Park S, Jang $\mathrm{H}$, Kim BS, Hwang C, Jeong GS, Park Y. Directional migration of mesenchymal stem cells under an SDF-1a gradient on a microfluidic device. PLoS One. 2017;12:e0184595. https://doi.org/10.1371/journal.pone.0184595.

78. de Witte SFH, Luk F, Sierra Parraga JM, Gargesha M, Merino A, Korevaar SS, et al. Immunomodulation by therapeutic mesenchymal stromal cells (MSC) is triggered through phagocytosis of MSC by monocytic cells. Stem Cells. 2018;36(4):602-15. https://doi.org/10.1002/stem.2779.

79. Weiss ARR, Dahlke MH. Immunomodulation by mesenchymal stem cells (MSCs): mechanisms of action of living, apoptotic, and dead MSCs. Front Immunol. 2019;10:1191. https://doi.org/10.3389/fimmu.2019.01191.

80. Sioud M, Mobergslien A, Boudabous A, Fløisand Y. Evidence for the involvement of galectin-3 in mesenchymal stem cell suppression of allogeneic T-cell proliferation. Scand J Immunol. 2010;71:267-74. https://doi. org/10.1111/j.1365-3083.2010.02378.x.

81. Sioud M. New insights into mesenchymal stromal cell-mediated T-cell suppression through galectins. Scand J Immunol. 2011;73:79-84. https://doi. org/10.1111/j.1365-3083.2010.02491.x.

82. Souza BSDF, Da Silva KN, Silva DN, Rocha VPC, Paredes BD, Azevedo CM, et al. Galectin-3 knockdown impairs survival, migration, and immunomodulatory actions of mesenchymal stromal cells in a mouse model of Chagas disease cardiomyopathy. Stem Cells Int. 2017;2017: 3282656-13. https://doi.org/10.1155/2017/3282656

83. Eleuteri S, Fierabracci A. Insights into the secretome of mesenchymal stem cells and its potential applications. Int J Mol Sci. 2019;20:4597. https://doi. org/10.3387/ijms20184597.
84. Torralba D, Baixauli F, Sánchez-Madrid F. Mitochondria know no boundaries: mechanisms and functions of intercellular mitochondrial transfer. Front Cell Dev Biol. 2016;4:107. https://doi.org/10.3389/fcell.2016.00107.

85. Weiss DJ, English K, Krasnodembskaya A, Isaza-Correa JM, Hawthorne IJ, Mahon BP. The necrobiology of mesenchymal stromal cells affects therapeutic efficacy. Front Immunol. 2019;10:1228. https://doi.org/10.3389/ fimmu.2019.01228.

86. Delgado-Roche L, Mesta F. Oxidative stress as key player in severe acute respiratory syndrome coronavirus (SARS-CoV) infection. Arch Med Res. 2020; 51:384-7. https://doi.org/10.1016/j.arcmed.2020.04.019.

87. Hoffmann RF, Zarrintan S, Brandenburg SM, Kol A, de Bruin HG, Jafari S, et al. Prolonged cigarette smoke exposure alters mitochondrial structure and function in airway epithelial cells. Respir Res. 2013;14:97. https://doi. org/10.1186/1465-9921-14-97.

88. Hoffmann RF, Jonker MR, Brandenburg SM, de Bruin $H G$, ten Hacken NHT, van Oosterhout AJM, et al. Mitochondrial dysfunction increases proinflammatory cytokine production and impairs repair and corticosteroid responsiveness in lung epithelium. Sci Rep. 2019;9:15047. https://doi.org/1 0.1038/s41598-019-51517-x.

89. Zhang D, Guo R, Lei L, Liu H, Wang Y, Wang Y, et al. COVID-19 infection induces readily detectable morphologic and inflammation-related phenotypic changes in peripheral blood monocytes. J Leukoc Biol. 2020. https://doi.org/10.1002/JLB.4HI0720-470R.

90. Saleh J, Peyssonnaux C, Singh KK, Edeas M. Mitochondria and microbiota dysfunction in COVID-19 pathogenesis. Mitochondrion. 2020;54:1-7. https:// doi.org/10.1016/j.mito.2020.06.008.

91. Islam MN, Das SR, Emin MT, Wei M, Sun L, Westphalen K, et al. Mitochondrial transfer from bone-marrow-derived stromal cells to pulmonary alveoli protects against acute lung injury. Nat Med. 2012;18:75965. https://doi.org/10.1038/nm.2736.

92. Li $X$, Zhang $Y$, Yeung SC, Liang $Y$, Liang $X$, Ding $Y$, et al. Mitochondrial transfer of induced pluripotent stem cell-derived mesenchymal stem cells to airway epithelial cells attenuates cigarette smoke-induced damage. Am J Respir Cell Mol Biol. 2014;51:455-65. https://doi.org/10.1165/rcmb.2013-052 $90 \mathrm{C}$.

93. Yao Y, Fan XL, Jiang D, Zhang Y, Li X, Xu ZB, et al. Connexin 43-mediated mitochondrial transfer of iPSC-MSCs alleviates asthma inflammation. Stem Cell Reports. 2018;11:1120-35. https://doi.org/10.1016/j.stemcr.2018.09.012.

94. Schulz KS, Mossman KL. Viral evasion strategies in type I IFN signaling - a summary of recent developments. Front Immunol. 2016;11(7):498. https:// doi.org/10.3389/fimmu.2016.00498. PMID: 27891131; PMCID: PMC5104748.

95. Kim DS, Jang IK, Lee MW, Ko YJ, Lee DH, Lee JW, et al. Enhanced immunosuppressive properties of human mesenchymal stem cells primed by interferon- $\gamma$. EBioMedicine. 2018;28:261-73. https://doi.org/10.1016/j. ebiom.2018.01.002 Epub 2018 Jan 9. PMID: 29366627; PMCID: PMC5898027.

96. Meisel R, Brockers S, Heseler K, Degistirici O, Bülle H, Woite C, et al. Human but not murine multipotent mesenchymal stromal cells exhibit broadspectrum antimicrobial effector function mediated by indoleamine 2,3dioxygenase. Leukemia. 2011;25(4):648-54. https://doi.org/10.1038/leu.201 0.310 .

97. Qian X, Xu C, Fang S, Zhao P, Wang Y, Liu H, et al. Exosomal microRNAs derived from umbilical mesenchymal stem cells inhibit hepatitis $C$ virus infection. Stem Cells Transl Med. 2016 Sep;5(9):1190-203.

98. Millar JE, Bartnikowski N, Passmore MR, Obonyo NG, Malfertheiner MV, von Bahr V, et al. Combined mesenchymal stromal cell therapy and ECMO in ARDS: a controlled experimental study in sheep. Am J Respir Crit Care Med. 2020;202:383-92. https://doi.org/10.1164/rccm.201911-2143oc.

99. Chen M, Huang Z, Hong BI, Xinghua PAN, Jian HE, Lewei HE, et al. Effects of bone marrow-derived mesenchymal stem cell transplantation on chronic obstructive pulmonary disease/obstructive sleep apnea overlap syndrome in rats. Mol Med Rep. 2019;20:4665-73. https:/doi.org/10.3892/mmr.2019.10714

100. Paliwal S, Chaudhuri R, Agrawal A, Mohanty S. Human tissue-specific MSCs demonstrate differential mitochondria transfer abilities that may determine their regenerative abilities. Stem Cell Res Ther. 2018;9:298. https://doi.org/1 0.1186/s13287-018-1012-0.

101. Romieu-Mourez R, François M, Boivin M-N, Bouchentouf M, Spaner DE, Galipeau J. Cytokine modulation of TLR expression and activation in mesenchymal stromal cells leads to a proinflammatory phenotype. Immunol. 2009;182(12):7963-73. https://doi.org/10.4049/jimmunol.0803864.

102. Khatri M, Richardson LA, Meulia T. Mesenchymal stem cell-derived extracellular vesicles attenuate influenza virus-induced acute lung injury in a 
pig model. Stem Cell Res Ther. 2018;9(1):17. https://doi.org/10.1186/s13287018-0774-8.

103. Barnes PJ. Inflammatory mechanisms in patients with chronic obstructive pulmonary disease. J Allergy Clin Immunol. 2016;138:16-27. https://doi.org/1 0.1016/j.jaci.2016.05.011.

104. Liu M, Chen F, Liu T, Chen F, Liu S, Yang J. The role of oxidative stress in influenza virus infection. Microbes Infect. 2017;19:580-6. https://doi.org/10.1 016/.micinf.2017.08.008.

105. Georgescu SR, Mitran Cl, Mitran Ml, Caruntu C, Sarbu Ml, Matei C, et al. New insights in the pathogenesis of HPV infection and the associated carcinogenic processes: the role of chronic inflammation and oxidative stress. J Immunol Res. 2018;2018:5315816. https://doi.org/10.1155/2018/531 5816.

106. Zhang L, Wei L, Jiang D, Wang J, Cong X, Fei R. SARS-CoV nucleocapsid protein induced apoptosis of COS-1 mediated by the mitochondrial pathway. Artif Cells, Blood Substitutes, Biotechnol. 2007;35:237-53. https:// doi.org/10.1080/10731187601188422.

107. Zhou F, Yu T, Du R, Fan G, Liu Y, Liu Z, et al. Clinical course and risk factors for mortality of adult inpatients with COVID-19 in Wuhan, China: a retrospective cohort study. Lancet. 2020;395:1054-62. https://doi.org/10.101 6/S0140-6736(20)30566-3.

108. Chan MCW, Kuok DIT, Leung CYH, Hui KPY, Valkenburg SA, Lau EHY, et al. Human mesenchymal stromal cells reduce influenza A H5N1-associated acute lung injury in vitro and in vivo. Proc Natl Acad Sci U S A. 2016;113: 3621-6. https://doi.org/10.1073/pnas.1601911113.

109. Loy H, Kuok DIT, Hui KPY, Choi MHL, Yuen W, Nicholls JM, et al. Therapeutic implications of human umbilical cord mesenchymal stromal cells in attenuating influenza $\mathrm{A}(\mathrm{H} 5 \mathrm{~N} 1)$ virus-associated acute lung injury. I Infect Dis. 2019;219(2):186-96. https://doi.org/10.1093/infdis/jiy478.

110. Li Y, Xu J, Shi W, Chen C, Shao Y, Zhu L, et al. Mesenchymal stromal cell treatment prevents H9N2 avian influenza virus-induced acute lung injury in mice. Stem Cell Res Ther. 2016;7:1-11. https://doi.org/10.1186/s13287-016-03 95-z.

111. Darwish I, Banner D, Mubareka S, Kim H, Besla R, Kelvin DJ, et al. Mesenchymal stromal (stem) cell therapy fails to improve outcomes in experimental severe influenza. PLoS One. 2013:8:e71761. https://doi.org/1 0.1371/journal.pone.0071761.

112. Gotts JE, Abbott J, Matthay MA. Influenza causes prolonged disruption of the alveolar-capillary barrier in mice unresponsive to mesenchymal stem cell therapy. Am J Physiol Lung Cell Mol Physiol. 2014;307:395-406. https:// doi.org/10.1152/ajplung.00110.2014.

113. Ikonomou L, Wagner DE, Gilpin SE, Weiss DJ, Ryan AL. Technological advances in study of lung regenerative medicine: perspective from the 2019 Vermont lung stem cell conference. Cytotherapy. 2020;22:519-20. https://doi.org/10.1016/j.jcyt.2020.04.089.

114. Panigada M, Bottino N, Tagliabue P, Grasselli G, Novembrino C, Chantarangkul V, et al. Hypercoagulability of COVID-19 patients in intensive care unit: a report of thromboelastography findings and other parameters of hemostasis. J Thromb Haemost. 2020;18:1738-42. https://doi.org/10.1111/ jth. 14850 .

115. Matthay MA, Calfee CS, Zhuo H, Thompson BT. Wilson JG, Levitt JE, et al. Treatment with allogeneic mesenchymal stromal cells for moderate to severe acute respiratory distress syndrome (START study): a randomised phase 2a safety trial. Lancet Respir Med. 2019;7:154-62. https://doi.org/10.1 016/S2213-2600(18)30418-1.

116. Jung JW, Kwon M, Choi JC, Shin JW, Park IW, Choi BW, et al. Familial occurrence of pulmonary embolism after intravenous, adipose tissuederived stem cell therapy. Yonsei Med J. 2013;54:1293-6. https://doi.org/1 0.3349/ymj.2013.54.5.1293.

117. Wu Z, Zhang S, Zhou L, Cai J, Tan J, Gao X, et al. Thromboembolism induced by umbilical cord mesenchymal stem cell infusion: a report of two cases and literature review. Transplant Proc. 2017;49:1656-8. https://doi. org/10.1016/j.transproceed.2017.03.078.

118. Moll G, Drzeniek N, Kamhieh-Milz J, Geissler S, Volk H-D, Reinke P. MSC therapies for COVID-19: importance of patient coagulopathy, thromboprophylaxis, cell product quality and mode of delivery for treatment safety and efficacy. Front Immunol. 2020;11:1091. https://doi.org/1 0.3389/fimmu.2020.01091.

119. Stéphenne X, Vosters O, Najimi M, Beuneu C, Ngoc DK, Wijns W, et al. Tissue factor-dependent procoagulant activity of isolated human hepatocytes: relevance to liver cell transplantation. Liver Transplant. 2007;13(4):599-606. https://doi.org/10.1002/lt.21128.

120. Beuneu C, Vosters O, Movahedi B, Remmelink M, Salmon I, Pipeleers D, et al. Human pancreatic duct cells exert tissue factor-dependent procoagulant activity: relevance to islet transplantation. Diabetes. 2004;53:1407-11. https:// doi.org/10.2337/diabetes.53.6.1407.

121. George MJ, Prabhakara K, Toledano-Furman NE, Wang Y, Gill BS, Wade CE, et al. Clinical cellular therapeutics accelerate clot formation. Stem Cells Transl Med. 2018;7(10):731-9. https://doi.org/10.1002/SCTM.18-0015@10.1 002/(ISSN)2157-6580.ADIPOSE-TISSUE-COLLECTION-2018.

122. Moll G, Ankrum JA, Kamhieh-Milz J, Bieback K, Ringdén O, Volk HD, et al. Intravascular mesenchymal stromal/stem cell therapy product diversification: time for new clinical guidelines. Trends Mol Med. 2019;25:149-63. https:// doi.org/10.1016/j.molmed.2018.12.006.

123. Ankrum JA, Ong JF, Karp JM. Mesenchymal stem cells: immune evasive, not immune privileged. Nat Biotechnol. 2014;32:252-60. https://doi.org/10.1038/ nbt.2816.

124. Kot M, Baj-Krzyworzeka M, Szatanek R, Musiał-Wysocka A, Suda-Szczurek M, Majka M. The importance of HLA assessment in "off-the-shelf" allogeneic mesenchymal stem cells based-therapies. Int J Mol Sci. 2019;20:5680. https://doi.org/10.3390/ijms20225680.

125. Moll G, Le Blanc K. Engineering more efficient multipotent mesenchymal stromal (stem) cells for systemic delivery as cellular therapy. ISBT Sci Ser. 2015;10:357-65. https://doi.org/10.1111/voxs.12133.

126. Moll G, Hult A, Von Bahr L, Alm JJ, Heldring N, Hamad OA, et al. Do ABO blood group antigens hamper the therapeutic efficacy of mesenchymal stromal cells? PLoS One. 2014;9(1):85040. https://doi.org/10.1371/journal. pone. 0085040 .

127. Guadix JA, López-Beas J, Clares B, Soriano-Ruiz UL, Zugaza JL, Gálvez-Martín P. Principal criteria for evaluating the quality, safety and efficacy of hMSCbased products in clinical practice: current approaches and challenges. Pharmaceutics. 2019;11:552. https://doi.org/10.3390/pharmaceutics11110552.

128. Kollerup Madsen B, Hilscher M, Zetner D, Rosenberg J. Adverse reactions of dimethyl sulfoxide in humans: a systematic review. F1000Research. 2018;7: 1746. https://doi.org/10.12688/f1000research.16642.1.

129. Shu Z, Heimfeld S, Gao D. Hematopoietic stem cell transplantation with cryopreserved grafts: adverse reactions after transplantation and cryoprotectant removal prior to infusion. Bone Marrow Transpl. 2014;49: 469-76. https://doi.org/10.1038/bmt.2013.152.

130. Sánchez-Guijo F, Garćá-Arranz M, López-Parra M, Monedero P, MataMartínez C, Santos A, et al. Adipose-derived mesenchymal stromal cells for the treatment of patients with severe SARS-CoV-2 pneumonia requiring mechanical ventilation. A proof of concept study. EClinicalMedicine. 2020; 25:100454. https://doi.org/10.1016/j.eclinm.2020.100454.

131. Thanunchai M, Hongeng S, Thitithanyanont A. Mesenchymal stromal cells and viral infection. Stem Cells Int. 2015;2015:860950. https://doi.org/10.11 55/2015/860950.

132. Johnson V, Webb T, Norman A, Coy J, Kurihara J, Regan D, et al. Activated mesenchymal stem cells interact with antibiotics and host innate immune responses to control chronic bacterial infections. Sci Rep. 2017;7:9575. https://doi.org/10.1038/s41598-017-08311-4.

133. Von Bahr L, Batsis I, Moll G, Hägg M, Szakos A, Sundberg B, et al. Analysis of tissues following mesenchymal stromal cell therapy in humans indicates limited long-term engraftment and no ectopic tissue formation. Stem Cells. 2012;30:1575-8. https://doi.org/10.1002/stem.1118.

134. Sato Y, Bando H, Di Piazza M, Gowing G, Herberts C, Jackman S, et al. Tumorigenicity assessment of cell therapy products: the need for global consensus and points to consider. Cytotherapy. 2019;21:1095-111. https:// doi.org/10.1016/j.jcyt.2019.10.001.

135. Thompson M, Mei SHJ, Wolfe D, Champagne J, Fergusson D, Stewart DJ, et al. Cell therapy with intravascular administration of mesenchymal stromal cells continues to appear safe: an updated systematic review and metaanalysis. EClinicalMedicine. 2020;19:100249. https://doi.org/10.1016/j.eclinm.2 019.100249

136. Zheng G, Huang L, Tong H, Shu Q, Hu Y, Ge M, et al. Treatment of acute respiratory distress syndrome with allogeneic adipose-derived mesenchymal stem cells: a randomized, placebo-controlled pilot study. Respir Res. 2014;15: 39. https://doi.org/10.1186/1465-9921-15-39.

137. Wilson JG, Liu KD, Zhuo H, Caballero L, McMillan M, Fang X, et al. Mesenchymal stem (stromal) cells for treatment of ARDS: a phase 1 clinical 
trial. Lancet Respir Med. 2015;3:24-32. https://doi.org/10.1016/S2213-2600(14 )70291-7.

138. Chen J, Hu C, Chen L, Tang L, Zhu Y, Xu X, et al. Clinical study of mesenchymal stem cell treatment for acute respiratory distress syndrome induced by epidemic influenza A (H7N9) infection: a hint for COVID-19 treatment. Engineering (Beijing). 2020;6:1153-61. https://doi.org/10.1016/j. eng.2020.02.006.

139. Shu L, Niu C, Li R, Huang T, Wang Y, Huang M, et al. Treatment of severe COVID-19 with human umbilical cord mesenchymal stem cells. Stem Cell Res Ther. 2020;11:36. https://doi.org/10.1186/s13287-020-01875-5.

140. Sengupta V, Sengupta S, Lazo A, Woods P, Nolan A, Bremer N. Exosomes derived from bone marrow mesenchymal stem cells as treatment for severe COVID-19. Stem Cells Dev. 2020;29:747-54. https://doi.org/10.1089/scd.2020. 0080.

141. Chen X, Shan Y, Wen Y, Sun J, Du H. Mesenchymal stem cell therapy in severe COVID-19: a retrospective study of short-term treatment efficacy and side effects. J Infection. 2020;81:647-79. https://doi.org/10.1016/j.jinf.2020.05. 020.

142. Zhang $Y$, Ding J, Ren $S$, Wang $W$, Yang $Y$, Li S, et al. Intravenous infusion of human umbilical cord Wharton's jelly-derived mesenchymal stem cells as a potential treatment for patients with COVID-19 pneumonia. Stem Cell Res Ther. 2020;11:207. https://doi.org/10.1186/s13287-020-01725-4.

143. Tang L, Jiang Y, Zhu M, Chen L, Zhou X, Zhou C, et al. Clinical study using mesenchymal stem cells for the treatment of patients with severe COVID19. Front Med. 2020;14:664-73. https://doi.org/10.1007/s11684-020-0810-9.

144. Mazzeo A, Santos E. Mesenchymal stem cells in the treatment of coronavirus-induced pneumonia (COVID-19). Einstein (Sao Paulo). 2020;18: eCE5802. https://doi.org/10.31744/einstein_journal/2020 CE5802.

145. Peng H, Gong T, Huang X, Sun X, Luo H, Wang W, et al. A synergistic role of covalescent plasma and mesenchymal stem cells in the treatment of severy ill COVID-19 patients: a clinical case report. Stem Cell Res Ther. 2020;11(1): 291. https://doi.org/10.1186/s13287-020-01802-8.

146. Guo Z, Chen Y, Luo X, He X, Zhang Y, Wang J. Administration of umbilical cord mesenchymal stem cells in patients with severe COVID-19 pneumonia. Crit Care. 2020;24:420. https://doi.org/10.1186/s13054-020-03142-8.

147. Liang S, Jiao HL, Chi LK, Shi XY, Liang AM, Tian Y, et al. Clinical remission of a critically ill COVID-19 patient treated by human umbilical cord mesenchymal stem cells. Chinese J Tissue Eng Res. 2020;16:9179-85. https:// doi.org/10.3969/j.issn.2095-4344.2012.49.011.

148. Meng F, Xu R, Wang S, Xu Z, Zhang C, Li Y, et al. Human umbilical cordderived mesenchymal stem cell therapy in patients with COVID-19: a phase 1 clinical trial. Signal Transduct Target Ther. 2020;5:172. https://doi.org/10.1 038/541392-020-00286-5.

149. Zhu Y, Zhu R, Liu K, Li X, Chen D, Bai D, et al. Human umbilical cord mesenchymal stem cells for adjuvant treatment of a critically ill COVID-19 patient: a case report. Infect Drug Resist. 2020;13:3295-300. https://doi.org/1 $0.2147 /$ IDR.S272645

150. Shi L, Huang H, Lu X, et al. Effect of human umbilical cord-derived mesenchymal stem cells on lung damage in severe COVID-19 patients: a randomized, double-blind, placebo-controlled phase 2 trial. Sig Transduct Target Ther. 2021;6:58 https://doi.org/10.1038/s41392-021-00488-5.

151. Hashemian SMR, Aliannejad R, Zarrabi M, et al. Mesenchymal stem cells derived from perinatal tissues for treatment of critically ill COVID-19-induced ARDS patients: a case series. Stem Cell Res Ther. 2021;12:91. https:/doi.org/1 0.1186/s13287-021-02165-4

152. Feng Y, Huang J, Wu J, et al. Safety and feasibility of umbilical cord mesenchymal stem cells in patients with COVID-19 pneumonia: a pilot study. Cell Prolif. 2020;53:e12947 https://doi.org/10.1111/cpr.12947.

153. Chu M, Wang H, Bian L, et al. Nebulization therapy with umbilical cord mesenchymal stem cell-derived exosomes for COVID-19 pneumonia. 2021. PREPRINT (Version 2) available at Research Square. https://doi.org/10.21203/ rs.3.rs-99753/v2

154. Lanzoni G, Linetsky E, Correa D, et al. Umbilical cord mesenchymal stem cells for COVID-19 acute respiratory distress syndrome: a double-blind, phase 1/2a, randomized controlled trial. STEM CELLS Transl Med. 2021:1-14. https://doi.org/10.1002/sctm.20-0472.

155. Cancio M, Ciccocioppo R, Rocco PRM, Levine BL, Bronte V, Bollard CM, et al. Emerging trends in COVID-19 treatment: learning from inflammatory conditions associated with cellular therapies. Cytotherapy. 2020;22:474-81. https://doi.org/10.1016/j.jcyt.2020.04.100
156. Wilson A, Hodgson-Garms M, Frith JE, Genever P. Multiplicity of mesenchymal stromal cells: finding the right route to therapy. Front Immunol. 2019;10:1112. https://doi.org/10.3389/fimmu.2019.01112.

157. Levy O, Kuai R, Siren EMJ, Bhere D, Milton Y, Nissar N, et al. Shattering barriers toward clinically meaningful MSC therapies. Sci Adv. 2020;6: eaba6884. https://doi.org/10.1126/sciadv.aba6884.

158. Bloor AJC, Patel A, Griffin JE, Gilleece MH, Radia R, Yeung DT, et al. Production, safety and efficacy of iPSC-derived mesenchymal stromal cells in acute steroid-resistant graft versus host disease: a phase I, multicenter, open-label, dose-escalation study. Nat Med. 2020). https://doi.org/10.1038/ s41591-020-1050-x;26(11):1720-5. https://doi.org/10.1038/s41591-020-1050-x.

159. Elverum K, Whitman M. Delivering cellular and gene therapies to patients: solutions for realizing the potential of the next generation of medicine. Gene Ther. 2020;27:537-54. https://doi.org/10.1038/s41434-019-0074-7.

\section{Publisher's Note}

Springer Nature remains neutral with regard to jurisdictional claims in published maps and institutional affiliations. 